Int. J. Dev. Biol. 53: 1581-1596 (2009)

doi: $10.1387 / \mathrm{ijdb} .072460 \mathrm{jj}$

\title{
Chromatin remodeling in plant development
}

\author{
JOSÉ A. JARILLO ${ }^{1, \#, ~ M A N U E L ~ P I N ̃ E I R O ~}{ }^{1, \#, ~ P I L A R ~ C U B A S ~}{ }^{2, \#}$ and JOSÉ M. MARTÍNEZ-ZAPATER*,2 \\ ${ }^{1}$ Departamento de Biotecnología, Instituto Nacional de Investigación y Tecnología Agraria y Alimentaria (INIA)-Centro de Biotecnología \\ y Genómica de Plantas (UPM-INIA) and 2Departamento de Genética Molecular de Plantas, Centro Nacional de Biotecnología (CNB-CSIC), \\ Madrid, Spain
}

\begin{abstract}
Plant development results from specific patterns of gene expression that are tightly regulated in a spatio-temporal manner. Chromatin remodeling plays a central role in establishing these expression patterns and maintaining epigenetic transcriptional states through successive rounds of mitosis that take place within a cell lineage. Plant epigenetic switches occur not only at the embryo stage, but also during postembryonic developmental transitions, suggesting that chromatin remodeling activities in plants can provide a higher degree of regulatory flexibility which probably underlies their developmental plasticity. Here, we highlight recent progress in the understanding of plant chromatin dynamic organization, facilitating the activation or repression of specific sets of genes involved in different developmental programs and integrating them with the response to environmental signals. Chromatin conformation controls gene expression both in actively dividing undifferentiated cells and in those already fate-determined. In this context, we first describe chromatin reorganization activities required to maintain meristem function stable through DNA replication and cell division. Organ initiation at the apex, with emphasis on reproductive development, is next discussed to uncover the chromatin events involved in the establishment and maintenance of expression patterns associated with differentiating cells; this is illustrated with the complex epigenetic regulation of the Arabidopsis floral repressor FLOWERING LOCUS C (FLC). Finally, we discuss the involvement of chromatin remodeling in plant responses to environmental cues and to different types of stress conditions.
\end{abstract}

KEY WORDS: chromatin, Arabidopsis, epigenetics, histone modification

\section{Introduction}

The embryonic development of plants defines the apical-basal axis of the seedling and establishes pools of stem cells that constitute the shoot and root meristems (SAM and RAM respectively), but the development of leaves, stems and flower meristems takes place sequentially during postembryonic stages of plant development. A dynamic balance between cell division and organ initiation in the flanks of the meristems provides the basis for the continuous organogenesis that characterizes plant development. A group of undifferentiated cells is maintained in the centre of each meristem throughout the entire life of the plant, while cells in the periphery give rise to growing primordia that progressively acquire the lateral organ identity. During their life cycle, plants undergo several developmental phases characterized by different types of growing primordia that give rise to particular organs with specific patterns of cell differentiation. The timing of the transition between developmental phases is controlled by a combination of endogenous and environmental signals, generating the characteristic plasticity of plant development that allows plant species to optimize their adaptation to the environment.

As in other multicellular organisms, developmental processes in plants result from specific patterns of gene expression that need to be tightly regulated in a spatial and temporal manner. Chromatin remodeling plays a central role in establishing these

\footnotetext{
Abbreviations used in this paper: HAT, histone acetyl transferase; HDAC, histone deacetylase; PAF, polymerase associated factor; PcG, Polycomb group; PRC, polycomb repressive complex; PRE, polycomb responsive element; RAM, root apical meristem; SAM, shoot apical meristem; TRE, trithorax responsive element; TrxG, trithorax group; VRE, vernalization response element.
}

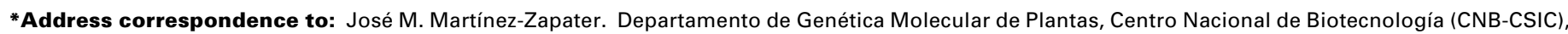
Darwin 3, Cantoblanco, Madrid 28049, Spain. Fax: +34-91-585-4506. e-mail: zapater@cnb.uam.es

\#Note: These authors contributed equally to this work.

Final author-corrected PDF published online: 14 January 2009.

ISSN: Online 1696-3547, Print 0214-6282

() 2009 UBC Press

Printed in Spain 
expression patterns and maintaining epigenetic transcriptional states through the successive rounds of mitosis that take place within a cell lineage (Reyes, 2006; Exner and Hennig, 2008). In contrast to animals where epigenetic states are established early during embryonic development, in plants, epigenetic mechanisms also operate during post-embryonic developmental transitions such as organogenesis and flowering (Henderson and Jacobsen, 2007). This suggests that chromatin remodeling activities in plants provide a higher degree of flexibility that probably underlies their developmental plasticity.

From a developmental perspective, chromatin organization participates in the control of gene expression patterns both in actively dividing undifferentiated cells and in differentiated cells. Meristems maintain stem cells, proliferating cells and differentiating cells that are progressively fate-restricted. In proliferating cells, meristem-specific gene expression needs to be maintained through mitosis and therefore conserved throughout DNA replication. Similarly, differentiating cells require maintaining stable repression of meristem genes and expression of transcriptional programs responsible for organ identity (Guyomarc'h et al., 2005; Köhler and Villar, 2008). At the same time, all cells need to be able to transcriptionally respond to specific environmental cues, either periodic such as light-dark cycles or random as stress conditions. Plant chromatin must display a very dynamic organization to activate or repress specific sets of genes involved in different developmental responses, allowing the integration of developmental programs with the response to environmental signals.

Nucleosomes are the basic structural units of chromatin in eukaryotic cells. Each nucleosome is composed of two turns of DNA wound around a histone octamer containing two $\mathrm{H} 2 \mathrm{~A}-\mathrm{H} 2 \mathrm{~B}$ dimers and one $\mathrm{H} 3-\mathrm{H} 4$ tetramer, and is connected to the next nucleosome by linker DNA. The nucleosome chains can be packaged into more condensed chromatin fibre structures, often found in transcriptionally inactive chromosomal regions. Proteins participating in chromatin remodeling fall in three major classes: histone chaperones, DNA and histone modification enzymes and ATP-dependent chromatin remodeling enzymes.

Histone chaperones prevent misfolding and aggregation of histones, facilitating their interaction with other molecules (Loyola and Almouzni, 2004; Ramirez-Parra and Gutierrez, 2007). They are often associated with other chromatin modifiers and with the DNA replication machinery, participating in chromatin remodeling processes and nucleosome deposition.

Both DNA and histones can be covalently modified in chromatin (Vaillant and Paszkowski, 2007). DNA methylation has been classically associated to gene silencing in inherited epigenetic events, and heterochromatin and transposons are heavily methylated (Hsieh and Fischer, 2005; Zhang et al., 2006). Covalent modifications of specific residues in the $\mathrm{N}$-terminal tails of the core histones such as acetylation, phosphorylation, methylation and ubiquitination affect nucleosome positioning and compaction, playing important roles in gene regulation (Kouzarides, 2007). The spectrum of histone modifications at a given locus is often referred to as the histone code, because the specific combination of modifications is thought to create a unique state of gene transcriptional activity (Strahl and Allis, 2000; Jenuwein and Allis, 2001; Pfluger and Wagner, 2007). Several histone acetyltransferases (HATs) are associated with transcription coactivators whereas histone deacetylases (HDACs) are often components of corepressor complexes in yeast and animal cells, indicating that histone acetylation is an integral part of transcriptional regulatory systems (Lee and Workman, 2007). Consistent with these findings hyperacetylation of histones is associated with transcriptional activation, whereas hypoacetylation of histones induces inactive chromatin conformations and gene repression (Carroza etal., 2003). Similarly, trimethylation of H3K4 (H3K4me3) and $\mathrm{H} 3 \mathrm{~K} 36 \mathrm{me} 3$ are hallmarks of active genes (Rando, 2007; Xu et al., 2008) whereas H3K9me3 and H3K27me3 are present in repressed regions of chromatin (Ringrose and Paro, 2007). These latter modifications can lead to mitotically stable repressed states of target genes through the recruitment of repressor complexes that may establish autoregulatory loops that propagate the silenced state throughout rounds of DNA replication (Pien and Grossniklaus, 2007). Moreover, several proteins and functional domains involved in recognition and translation of the histone code into patterns of gene expression have been recently identified, and this is likely to be an area of active research in the near future (Becker, 2006; Mellor, 2006).

In addition, ATP-dependent chromatin-remodeling enzymes can modify the interactions between the DNA and the histone octamer, destabilizing nucleosome structure and allowing the transcriptional machinery to access the DNA (Smith and Peterson, 2005; Kwon and Wagner, 2007; van Vugt et al., 2007). Finally, recent findings indicate the relevance of the spatial distribution of genes within the nucleus in their transcriptional control (Sexton et al., 2007; Singh etal., 2008). The topology of the chromatin where a particular gene is located could determine its proper expression in the context of a developmental program, revealing a mechanistic link between gene position, and gene expression (Sexton et al., 2007). The combined action of all these mechanisms modulates the structural dynamics of chromatin and defines the transcriptional state on target loci.

In this review, we highlight recent progress made in the understanding of the role of chromatin modification in plant development, using Arabidopsis as a model species. Plant developmental processes are considered in the context of cell proliferation and differentiation. Developmental processes at the meristem are first considered as they involve chromatin events that need to be stable through DNA replication and cell division. Organ differentiation at different stages of development will be then discussed to review the available information on chromatin events involved in establishment and maintenance of expression patterns associated to differentiated cells. These will be illustrated in depth with recent progress concerning the regulation of the Arabidopsis floral repressor FLC. Finally, we will describe the current information on the involvement of chromatin remodeling in the response to environmental cues such as light and temperature and to different types of abiotic stress.

\section{Chromatin modification events required to establish and maintain proper meristem activity}

The SAM and RAM are responsible for the continuous growth and development of the aerial and underground structures of the plant. Both meristems contain groups of pluripotent stem cells (Verdeil et al., 2007). In the SAM, stem cells are located in the central region of the meristem and pluripotency is maintained by signals generated by cells of the so-called organizing centre, that 
TABLE 1

\section{GENES CITED IN THE TEXT AS INVOLVED IN CHROMATIN REMODELLING}

\begin{tabular}{|c|c|c|}
\hline Gene & Homology and function & References \\
\hline$A D A 2 a, A D A 2 b$ & $\begin{array}{l}\text { TRANSCRIPTIONAL ADAPTOR 2a and 2b; coactivator proteins that interact with GCN5; involved in the stimulation of cold-regulated gene expression by } \\
\text { CBF1 }\end{array}$ & $\begin{array}{l}\text { Stockinger et al., 2001; } \\
\text { Vlachonasios et al., } 2003\end{array}$ \\
\hline AtBRM & $\begin{array}{l}\text { AtBRAHMA; SWI/SNF (SWITCH/SUCROSE NONFERMENTING) ATP-dependent chromatin remodeling enzyme with a role in SAM maintenance and also } \\
\text { required for proper acquisition of floral organ identity }\end{array}$ & $\begin{array}{l}\text { Farrona et al., 2004; Hurtado et } \\
\text { al., 2006; Kwon et al., 2006; } \\
\text { Su et al., } 2006\end{array}$ \\
\hline AtCHR12 & $\begin{array}{l}\text { AtCHROMATIN-REMODELING PROTEIN 12; SNF2/Brahma-type ATPase; mediates the establishment of a temporary growth arrest that allows adaptation } \\
\text { to adverse conditions }\end{array}$ & Mlynarova et al., 2007 \\
\hline AtCZS & $\begin{array}{l}\text { Plant-specific } \underline{\mathrm{C}} 2 \mathrm{H} 2 \text { Zinc finger-SET domain protein; interacts to AtSWP1 and regulates K9 and K27 dimethylation of histone } \mathrm{H} 3 \text { and hyperacetylation of } \\
\text { histone } \mathrm{H} 4 \text { within the } F L C \text { locus }\end{array}$ & Krichevsky et al., 2007 \\
\hline AtSWC6/SEF1 & AtSWC6/SERRATED AND EARLY FLOWERING 1; a HIT-Zinc finger containing protein of the SWR1 complex; regulates FLC and FLC-like expression & $\begin{array}{l}\text { Choi et al., 2007; March-Diaz } \\
\text { et al., 2007; Lazaro et al., } 2008\end{array}$ \\
\hline $\begin{array}{l}\text { AtSWI3c, } \\
\text { AtSWI3d }\end{array}$ & AtSWI3; SWI/SNF ATPases that perform nonredundant regulatory functions that affect embryogenesis and both the vegetative and reproductive phases & Sarnowski et al., 2005 \\
\hline AtSWP1/LDL1 & $\begin{array}{l}\text { AtSWIRM domain polyamine oxidase protein; member of the Lysine Demethylase LSD1 family; regulates K9 and K27 dimethylation of histone H3 and } \\
\text { hyperacetylation of histone H4 within the FLC locus }\end{array}$ & $\begin{array}{l}\text { Jiang et al., 2007; } \\
\text { Krichevsky et al., } 2007\end{array}$ \\
\hline ATX-1 & TRITHORAX 1; SET domain protein that displays H3K4 methyl transferase activity; activates flower homeotic genes & Alvarez-Venegas et al., 2003 \\
\hline $\begin{array}{l}\text { BRU1/MGO3/ } \\
\text { TSK }\end{array}$ & $\begin{array}{l}\text { BRUSHY1/MGOUN3/TONSOKU; possesses leucine-glycine-asparagine (LGN) and leucine-rich repeats (LRR); could be part of a nuclear protein complex } \\
\text { involved in SAM and RAM organization }\end{array}$ & $\begin{array}{l}\text { Guyomarc'h et al., 2004; } \\
\text { Takeda et al., 2004; } \\
\text { Suzuki et al., } 2005\end{array}$ \\
\hline CLF & $\begin{array}{l}\text { CURLY LEAF; PRC2 component; putative E(z) homologue with a SET domain responsible for H3K27me3 activity; necessary for stable repression of } \\
\text { AGAMOUS floral homeotic gene }\end{array}$ & Goodrich et al., 1997 \\
\hline DET1 & $\begin{array}{l}\text { DE-ETIOLATED1; part of a protein complex (CDD) containing DDB1, a protein that interacts with HAT complexes; controls light regulated gene expression } \\
\text { through chromatin remodeling }\end{array}$ & Pepper et al., 1994 \\
\hline EBS & $\begin{array}{l}\text { EARLY BOLTING IN SHORT DAYS; plant-specific nuclear protein that contains BAH and PHD Zn finger motifs; represses } F T \text { and vegetative expression of } \\
\text { floral organ identity genes as well as germination during the dormancy period }\end{array}$ & Piñeiro et al., 2003 \\
\hline EFS/SDG8 & $\begin{array}{l}\text { EARLY FLOWERING IN SHORT DAYS; SET domain-histone methyltransferase associated to the PAF1 complex; may antagonize PcG repression of } \\
\text { developmental master genes }\end{array}$ & Kim et al., 2005; Zhao et al., 2005 \\
\hline ELF7 & EARLY FLOWERING 7; relative of yeast RNA polymerase II (Pol II) Associated Factor 1 (PAF1); regulates FLC and FLC-like expression & He et al., 2004; Oh et al., 2004 \\
\hline ELF8 & EARLY FLOWERING 8; relative of yeast CLN Three Requiring 9 (CTR9), component of PAF1 complex; regulates FLC and FLC-like expression & He et al., 2004; Oh et al., 2004 \\
\hline EMF2 & EMBRYONIC FLOWER 2; PRC2 component; putative Su(z)12 homologue; involved in shoot development and repression of flowering & Yoshida et al., 2001 \\
\hline $\begin{array}{l}\text { ESD1/SUF3/ } \\
\text { ARP6 }\end{array}$ & $\begin{array}{l}\text { EARLY IN SHORT DAYS1/SUF3/ACTIN RELATED PROTEIN 6; component of the SWR1 complex that catalyzes the replacement of nucleosomal H2A by } \\
\text { the H2A.Z variant; related to ARP6; regulates FLC and FLC-like expression }\end{array}$ & $\begin{array}{l}\text { Choi et al., 2005; Deal et al., } \\
\text { 2005; Martin-Trillo et al., } 2006\end{array}$ \\
\hline FAS1 & FASCIATA1; subunit of the CAF1, involved in de novo nucleosome assembly during DNA replication; participates In RAM and SAM organization & Kaya et al., 2001 \\
\hline FAS2 & FASCIATA2; subunit of the CAF1, involved in de novo nucleosome assembly during DNA replication; participates in RAM and SAM organization & Kaya et al., 2001 \\
\hline FIE & $\begin{array}{l}\text { FERTILIZATION INDEPENDENT ENDOSPERM; PRC2 component; putative Enhancer of Zeste }(E(z) \text { homologue; WD-40 protein involved in the repression } \\
\text { of endosperm development in the absence of fertilization }\end{array}$ & $\begin{array}{l}\text { Kinoshita et al., 2001; } \\
\text { Katz et al., 2004; }\end{array}$ \\
\hline FIS2 & $\begin{array}{l}\text { FERTILIZATION INDEPENDENT SEED 2; PRC2 component; putative Suppressor of Zeste12 (Su(z)12) homologue; C2H2 zinc-finger protein involved in the } \\
\text { repression of endosperm development in the absence of fertilization }\end{array}$ & Ohad et al., 1999 \\
\hline FLD & $\begin{array}{l}\text { FLOWERING LOCUS D; homologue to human KIAA0601/Lysine Demethylase } 1 \text { (LSD1); also present in HDAC complexes and involved in the deacetylation } \\
\text { of the FLC locus }\end{array}$ & He et al., 2003 \\
\hline FVE/MSI4 & $\begin{array}{l}\text { MULTICOPY SUPPRESSOR OF IRA 4; a MSI-like protein involved in the deacetylation of the FLC locus; also acts as a negative regulator of the CBF } \\
\text { pathway }\end{array}$ & $\begin{array}{l}\text { Ausin et al., 2004; } \\
\text { Kim et al., } 2004\end{array}$ \\
\hline GCN5 & $\begin{array}{l}\text { GENERAL CONTROL OF AMINO ACID SYNTHESIS PROTEIN 5-LIKE 2; a histone acetyl transferase acting at several light-responsive genes; also } \\
\text { interacts with CBF1 and could be involved in the stimulation of cold-regulated gene expression by CBF1 }\end{array}$ & $\begin{array}{l}\text { Bertrand et al., 2005; } \\
\text { Benhamed et al., } 2006\end{array}$ \\
\hline HD1 & HISTONE DEACETYLASE 1; deacetylase acting at several light-responsive genes & $\begin{array}{l}\text { Bertrand et al., 2005; } \\
\text { Benhamed et al., } 2006\end{array}$ \\
\hline LHP1/TFL2 & $\begin{array}{l}\text { HETEROCHROMATIN PROTEIN } 1 \text { /TERMINAL FLOWER 2; may perform PRC1 functions in Arabidopsis; it associates in vivo with genes marked by } \\
\text { H3K27me3; involved in the regulation of euchromatic genes such as FLC, } A P 3, P I, A G \text { and } F T\end{array}$ & $\begin{array}{l}\text { Gaudin et al., 2001; Mylne et al., } \\
\text { 2006; Sung et al., 2006b; Turck } \\
\text { et al., 2007; Zhang et al., 2007b }\end{array}$ \\
\hline MEA & $\begin{array}{l}\text { MEDEA; PRC2 component; putative } \mathrm{E}(\mathrm{z}) \text { homologue with a SET domain responsible for H3K27me3 activity; regulates embryo, endosperm and seed } \\
\text { development }\end{array}$ & Grossniklaus et al., 1998 \\
\hline MSI1 & $\begin{array}{l}\text { MULTICOPY SUPPRESSOR OF IRA1; subunit of the CAF1, involved in de novo nucleosome assembly during DNA replication; participates in RAM and } \\
\text { SAM organization; also PRC2 component, putative p55 homologue }\end{array}$ & Kaya et al., 2001 \\
\hline NRP1, NRP2 & $\begin{array}{l}\text { NAP1-RELATED PROTEIN } 1 \text { and 2; homologues of the NUCLEOSOME ASSEMBLY PROTEIN1; bind histones H2A and H2B and associate with chromatin } \\
\text { in vivo; participate in root patterning }\end{array}$ & Zhu et al., 2006 \\
\hline PIE1 & PHOTOPERIOD INDEPENDENT EARLY FLOWERING 1; ATPase subunit of the SWR1 complex; regulates FLC and FLC-like expression & Noh et al., 2003 \\
\hline$P K L$ & $\begin{array}{l}\text { PICKLE; SWI/SNF involved in the suppression of embryonic and meristematic characteristics during development, and in the control of gene expression } \\
\text { during primordia initiation and floral patterning }\end{array}$ & Ogas et al., 1999 \\
\hline REF6 & $\begin{array}{l}\text { RELATIVE OF EARLY FLOWERING 6; member of Arabidopsis jumonji-containing factors related to mammalian proteins involved in demethylation of } \mathrm{K} \\
\text { residues in different positions of histone } \mathrm{H} 3\end{array}$ & Noh et al., 2004 \\
\hline SKB1/AtPRMT5 & $\begin{array}{l}\text { SHK1 BINDING PROTEIN 1; homolog of a human arginine methylase (PRMT5) that catalyses the symmetric dimethylation of H4R3 (H4R3sme2) and binds } \\
\text { to the FLC promoter }\end{array}$ & $\begin{array}{l}\text { Pei et al., 2007; Wang et al., } \\
\text { 2007; Schmitz et al., } 2008\end{array}$ \\
\hline SUF4 & $\begin{array}{l}\text { SUPPRESSOR OF FRIGIDA 4; a C2H2-type zinc finger protein that represses flowering by transcriptional activation of } F L C \text {; could function as an } \\
\text { intermediate to recruit the PAF1 complex to FLC chromatin }\end{array}$ & $\begin{array}{l}\text { Kim and Michaels, 2006; } \\
\text { Kim et al., } 2006\end{array}$ \\
\hline SWN & $\begin{array}{l}\text { SWINGER; PRC2 component; putative E(z) homologue with a SET domain responsible for H3K27me3 activity; controls initiation of seed development and } \\
\text { flowering }\end{array}$ & Chanvivattana et al., 2004 \\
\hline$S Y D$ & SPLAYED; SWI/SNF ATP-dependent chromatin remodeling enzyme required to maintain shoot meristem function & Wagner and Meyerowitz, 2002 \\
\hline TAF1 & TATA-BINDING PROTEIN (TBP)-ASSOCIATED FACTOR 1; a histone acetyl transferase acting at several light-responsive genes & $\begin{array}{l}\text { Bertrand et al., 2005; } \\
\text { Benhamed et al., } 2006\end{array}$ \\
\hline VIL1/VRN5 & VIN3-LIKE1/ VERNALIZATION INSENSITIVE 5; a VIN3-interacting protein required for a proper vernalization response & $\begin{array}{l}\text { Sung et al., 2006a; } \\
\text { Greb et al., } 2007\end{array}$ \\
\hline VIN3 & $\begin{array}{l}\text { VERNALIZATION INSENSITIVE 3; a PHD-containing protein required for histone deacetylation in the FLC region following vernalization; it is found as part } \\
\text { of the VRN2-PRC2 }\end{array}$ & Sung and Amasino, 2004 \\
\hline VIP4 & VERNALIZATION INDEPENDENT 4; relative of yeast Le01, a component of PAF1 complex; regulates FLC and FLC-like expression & Zhang and van Nocker,, 2002 \\
\hline VRN2 & VERNALIZATION 2; PRC2 component; putative Su(z)12 homologue; it represses FLC expression in response to vernalization & Gendall et al., 2001 \\
\hline
\end{tabular}




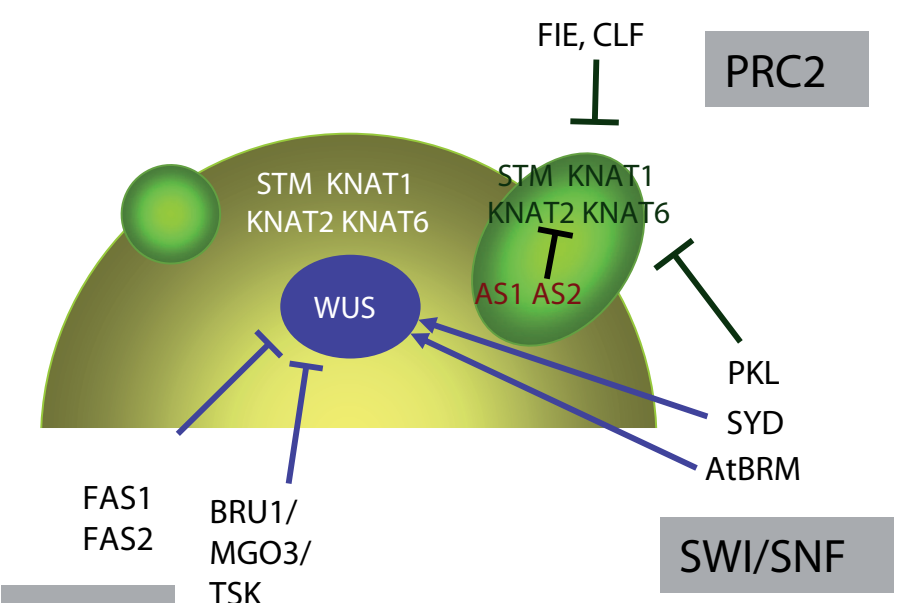

Fig. 1. Chromatin remodeling factors control the correct expression of meristem-specific genes. FASCIATA 1 (FAS1) and FAS2, members of the Chromatin Assembly Factor (CAF-1) complex and BRU1/MGO3/ TSK are required to determine the correct spatial expression of WUSCHEL (WUS), preventing its ectopic expression outside the organizing centre. The SWI/SNF factor SPLAYED (SYD) and, probably AtBRAHMA (AtBRM), ensure high levels of WUS within its expression domain. The SWI/SNF protein PICKLE (PKL) also acts, together with ASYMMETRIC LEAVES1 (AS1), to repress the KNOX genes STM, KNAT1, KNAT2 and KNAT6 in developing lateral organs while the polycomb-group proteins CURLY LEAF (CLF) and FERTILIZATION-INDEPENDENT ENDOSPERM (FIE) participate in this repression in newly formed primordia.

prevent differentiation of the stem cells (Scheres, 2007). Daughter cells, surrounding the stem cells, divide more rapidly and provide the founder cel/s that will generate lateral organs and the main stem. Underlying the stem cells, a group of cells expressing the homeobox gene WUSCHEL (WUS) form the organizing centre (Figure 1; See Table I for a list of genes involved in chromatin remodeling). A feedback loop between these cells and the stem cells, expressing the signaling gene CLAVATA3 (CLV3), maintains the constant size of the stem cell niche. In the RAM, stem cells are arranged around the organizing cells of the quiescent centre that express the gene WOX5 (WUSCHEL-RELATED HOMEOBOX 5, Haecker et al., 2004; Sarkar et al., 2007). Stem cells generate regular files of daughter cells which divide rapidly in a stereotyped manner. Descendants of these cells stop dividing and begin to elongate. In the SAM, in addition to the $C L V-W U S$ pathway, KNOXgenes (SHOOTMERISTEMLESS(STM), KNOTTED1-like ARABIDOPSIS THALIANA 1 (KNAT1), KNAT2 and $K N A T 6)$ act in the meristem cells to prevent premature cell differentiation (Figure 1).

It is not yet known how stem cells are maintained in a pluripotent state and, at the same time, are able to generate a progeny in which differentiation pathways are rapidly activated. However, increasing evidence, both in plants and animals, indicate that chromatin modifications help restrict and stabilize expression patterns in the stem cells progeny (Sablowski, 2004; Scheres, 2007). Recent experiments in animals indicate that stem-cell chromatin maintains genes involved in cell differentiation repressed whereas it allows transcription of proliferation factors and stem-cell regulators (Boyer etal., 2006; Lee etal., 2006a; Scheres,
2007; Verdeil et al., 2007). In plants, mutations at different genes coding for chromatin factors that preserve epigenetic marks through cell division, dramatically affect meristem size and organization as well as expression patterns of meristem genes suggesting that chromatin structure plays an important role in controlling this dynamic process (Goodrich and Tweedie, 2002). This is the case of mutants altered in the Chromatin-Assembly Factor-1 (CAF1), a histone-binding protein complex which participates in de novonucleosome assembly during DNA replication (RamírezParra and Gutiérrez, 2007). CAF1 is formed by three subunits conserved in all eukaryotes that in Arabidopsis are encoded by FASCIATA1 (FAS1), FAS2and MUL TICOPY SUPPRESSOROF IRA1 (MSI1) (Kaya et al., 2001; Hennig et al., 2003; Kirik et al., 2006; Ono et al., 2006). CAF1 seems to be necessary to ensure the stable inheritance and maintenance of epigenetic states during DNA replication (Kaya et al., 2001). Indeed, fas 1 mutants display a stochastic release of Transcriptional Gene Silencing (TGS) and overexpression of genes located in heterochromatic genomic regions (Ono et al., 2006). In addition, the expression of stem-cell regulatory genes such as WUS is severely altered (Figure 1; Kaya et al., 2001). In fasmutants, epigenetic repressing signals in WUS chromatin are stochastically lost and WUS transcription occurs in ectopic patches. As a result, fas mutants display overproliferation and fasciation of the SAM, aberrant SAM organization and defects in the stem cell pool size (Kaya et al., 2001; Ono et al., 2006). Mutants in another Arabidopsis gene BRUSHY1(BRU1)/MGOUN3(MGO3)/TONSOKU(TSK), are strikingly similar to fas mutants (Guyomarc'h et al., 2004; Takeda et al., 2004; Suzuki et al., 2005). The structure of the BRU1/MGO3/ TSK protein suggests that it could also be part of a nuclear protein complex involved in chromatin organization. Epistatic analyses suggest that BRU1 and FAS1 might also have common targets (Guyomarc'h etal., 2004; Suzuki etal., 2004; Takeda etal., 2004).

A different type of histone chaperones have been proposed to be involved in RAM maintenance and organization. The Arabidopsis homologues of the NUCLEOSOME ASSEMBLY PROTEIN1 (NAP1) gene, NAP1-RELATED PROTEIN1 and 2 (NRP1 and NRP2) encode proteins that bind histones $\mathrm{H} 2 \mathrm{~A}$ and $\mathrm{H} 2 \mathrm{~B}$ and associate with chromatin in vivo. Double mutants nrp1 nrp2 display impaired post-embryonic root growth, arrest of cell cycle progression at G2/M and disordered cellular organization in root tips; these mutants also exhibit perturbed expression of genes involved in root proliferation and patterning, and release of TGS (Zhu et al., 2006). All these data indicate that the correct functions of CAF1 and other histone chaperone complexes involved in the maintenance of chromatin epigenetic marks are essential for meristem function.

In contrast to the CAF1 complex, necessary to spatially restrict WUS expression to the organizing centre, SWI/SNF ATP-dependent chromatin remodeling enzymes are required to maintain shoot meristem function by ensuring appropriate levels of WUS transcript within its normal expression domain (Kwon and Wagner, 2007). The SWI/SNF protein SPLAYED (SYD) is recruited to the WUSpromoter and controls its transcription thus directly affecting the stem cell pool maintenance (Figure 1; Kwon et al., 2005). syd plants exhibit decreased WUSexpression, premature termination of the SAM, and carpelloid structures are formed after the inflorescence meristem has produced a few flowers (Wagner and Meyerowitz, 2002). Mutations in BRAHMA (AtBRM), mostly ex- 
pressed in meristems and proliferating tissue, also show reduction in size of the inflorescence meristem and in the number of flowers, suggesting that AtBRM also might have a role in SAM maintenance (Figure 1; Farrona et al., 2004; Hurtado et al., 2006; Kwon et al., 2006; Su etal., 2006). All these observations confirm the crucial role of chromatin remodeling in the regulation of meristem activity.

\section{Chromatin organization mediates the establishment and maintenance of gene expression patterns associ- ated with organ initiation and cell differentiation}

As cell proliferation proceeds in the growing primordia at the peripheral zone of the SAM, chromatin remodeling processes also play a central role in establishing transcriptional programs required for organ initiation and differentiation. First, it is important for the sequential production of lateral organs to keep meristem genes stably repressed outside the meristematic region. Second, it is necessary to ensure steady expression of differentiation genes in developing tissues and organs (leaf primordia, floral organs etc.), and repression of these genes in the domains where they have to be silenced so that the correct identity of growing organs is achieved. The Polycomb-Group (PcG) and Trithoraxgroup (TrxG) genes play key roles in these repressive and activating activities, respectively (Pien and Grossniklaus, 2007; Table I). The PcG proteins act as memory factors to stabilize repressive states of homeotic gene expression and the TrxG proteins establish transcriptionally active state of differentiation genes. SWI/SNF chromatin remodelers also play key roles in the control of the expression of genes involved in organ initiation and cell differentiation.

\section{Establishment of repressive states}

A pivotal level in the control of primordium fate is established by PcG protein complexes. Two types of Polycomb Repressive Complexes (PRC) have been described in animals, PRC1 and PRC2 which are responsible for the establishment of gene repression (PRC2) and maintenance of the repressive state (PRC1). The PRC2 complex promotes H3K27 methylation in target loci (Pien and Grossniklaus, 2007). These histone modifications regulate the accessibility of the transcriptional machinery to target genes leading to gene repression. The PRC2 complex in Drosophila is formed by four core proteins: Enhancer of Zeste $(E(z))$, Extra Sex Comb (ESC), p55 and Suppressor of zeste 12 (Su(z)12) (Muller et al., 2002). The proteins that constitute the PRC2 complex in animals are conserved in plants. However, contrary to what has been observed in animals, in plants some of the subunits of these protein complexes are encoded by small gene families, which suggests the existence of different PRC complexes regulating diverse developmental programs. In Arabidopsis, the ESC homolog is encoded by a single copy gene FERTILIZATION INDEPENDENT ENDOSPERM (FIE); however, the other PRC2 subunits have more than one homolog: EMBRYONIC FLOWER 2 (EMF2), FIS2 and VERNALIZATION 2 (VRN2) are homologs of Su(z)12, while MEDEA (MEA), CURLY LEAF (CLF) and SWINGER (SWN) are homologs of the $E(z)$ protein that contains a SET domain responsible for the Histone MethylTranferase (HMTase) activity of PRC2 complexes. Finally, the p55 homolog is encoded by $M S / 1$, a gene belonging to a five member gene family, although only MSI1 has been proposed to be part of the PRC2 complex (Calonje and Sung, 2006; Köhler and Villar, 2008).

During organ initiation, the PcG-proteins FIE, encoding a WD40 protein, and CLF are required to maintain the meristemspecific genes STM, KNAT1, KNAT2 and KNAT6 repressed in the newly formed primordia (Figure 1). In fiemutants, these genes are ectopically expressed in leaves while in clfmutants STMand KNAT2 are de-repressed (Goodrich et al., 1997; Katz et al., 2004). Moreover, it has been demonstrated that CLF binds to the STM locus and that CLF and SWN have partially redundant functions in the H3K27 trimethylation of the STMgene (Makarevich et al., 2006). Besides their role in repressing the homeobox gene STM, CLF and to some extent SWN, probably provide the HMTase activity required for the repression of the floral homeotic gene AGAMOUS (AG) in vegetative tissues (Goodrich etal., 1997; Katz etal., 2004). Recently both STMand $A G$ were shown to constitute direct targets of CLF, and also to carry dispersed H3K27me3 and localised H3K27me2 in leaf tissues; methylation in H3K27 was present in the $A G$ locus throughout leaf development and was strictly dependent on CLF activity that is required for persistent silencing of this gene in leaves (Schubert et al., 2006). In contrast to animals where H3K27me3 occupies large genomic regions, in Arabidopsis H3K27me3 enriched domains are essentially restricted to the transcribed regions of particular genes, suggesting that the mechanisms underlying the establishment and spreading of H3K27me3 might be significantly different in plants and animals (Zhang et al., 2007a). CLF and SWN have been shown to interact with EMF2, suggesting that either CLF or SWN and EMF2 could be part of a PRC2-like complex involved in the repression of $A G$ (Chanvivattana et al., 2004). FIE is also likely to be a component of this complex and recent findings support this view. The embryo lethal phenotype of fie mutants prevented for a long time the identification of any possible role of FIE during postembryonic development; however, plants partially depleted of FIE activity by means of cosuppression or partial complementation have revealed additional roles for FIE in the repression of homeobox genes, in the maintenance of root identity or in the repression of floral homeotic genes such as $A G, A P E T A L A 3$ (AP3) and PISTILLATA (PI) (Kinoshita et al., 2001; Katz et al., 2004).

Another PRC2 complex that plays a central role in the regulation of gametophyte, embryo and endosperm development was originally defined on the basis of Arabidopsis mutations that cause the development of seed-like structures in the absence of fertilization (reviewed in Kohler and Makarevich, 2006). The identified loci collectively referred to as FERTILIZATION INDEPENDENT SEED (FIS) class of genes, included MEA, FIE, MSI1 and F/S2. This PRC2-MEA complex is required to repress the expression of the PHERES1 (PHE1) MADS box gene and other genes normally expressed during early stages of endosperm development (Makarevich et al., 2006; Pien and Grossniklaus, 2007); PHE1 repression is at least partly dependent on MEA activity, although CLF and SWN appear to have partially redundant roles in this repression (Kohler et al., 2003; Makarevich etal., 2006). All these observations provide evidence for the existence of different types of PRC2 complexes in plants that in vivo methylate $\mathrm{H} 3 \mathrm{~K} 27$ residues in the genomic regions of their target genes (Calonje and Sung, 2006; Pien and Grossniklaus, 2007). FIE is probably present in all these complexes while other components with different spatio-temporal expression patterns change 
during plant development, providing a way to regulate different target genes at specific stages of development. Moreover, the analyses of double mutants affected in more than one PcG gene have revealed severe defects in development suggesting that partial redundancy and embryo lethality had masked until now some of the key roles that PRC2 protein complexes play in the regulation of plant developmental transitions.

\section{Maintenance of repressive states}

Once a given repressive state is established by PRC2, maintenance of this state in animals depends on a second Polycomb Repressive Complex (PRC1) (Köhler and Villar, 2008, Schwartz and Pirrota, 2008). This complex contains four core subunits and is proposed to bind H3K27me3 marks established by PRC2 in target loci; the activity of $\mathrm{PRC} 1$ is responsible for the monoubiquitination of residue $\mathrm{K} 119$ of histone $\mathrm{H} 2 \mathrm{~A}$, a modification that generates the stable silencing of target genes (Pien and Grossniklaus, 2007). In Arabidopsis neither homologues of the PRC1 components nor ubiquitinated H2AK119 have been identified so far, suggesting that plants could use a different mechanism to maintain stable silencing. In fact, recent reports have provided evidence that LIKE HETEROCHROMATIN PROTEIN 1 (LHP1)/TERMINAL FLOWER 2 (TFL2), a plant homologue of HP1, may perform PRC1 functions in Arabidopsis (Mylne et al., 2006; Sung et al., 2006b; Turck et al., 2007; Zhang et al., 2007b). Animal HP1 is a chromodomain protein that binds methylated $\mathrm{H} 3 \mathrm{~K} 9$ and is strongly associated with constitutive heterochromatin (Hediger and Gasser, 2006), although is not involved in Polycomb repression. However, Arabidopsis LHP1 does not appear to have a role in the maintenance of constitutive heterochromatin (Libault et al., 2005; Nakahigashi et al., 2005), and seems to be involved in the regulation of euchromatic genes, such as FLC, AP3, PI, AG and FT (Nakahigashi et al., 2005; Germann et al., 2006; Sung et al., 2006b; Turck et al., 2007). LHP1 specifically associates in vivo with genes marked by the trimethylation of $\mathrm{H} 3 \mathrm{~K} 27$, although it is not involved in this histone modification (Turck et al., 2007; Zhang etal., 2007b), suggesting that LHP1 might contribute to PcG-mediated silencing in a PRC1-like analogous manner.

\section{Establishment of active states of gene expression}

Groups of genes repressed by PcG complexes need to be active at particular developmental stages to promote the differentiation of specific organs. In animals, this activity, required to antagonize PRC repression and promote developmental processes, is provided by the TrxG group of proteins (Pien and Grossniklaus, 2007). As for PcG proteins, some TrxG proteins are also conserved in plants and several homologues have been identified in Arabidopsis; among them, TRITHORAX 1 (ATX-1) contains a SET domain and displays $\mathrm{H} 3 \mathrm{~K} 4$ methyl transferase activity in vitro(Alvarez-Venegas et al., 2003); consistent with this, atx 1 mutants have moderately low levels of genomic H3K4 methylation. This partial reduction of H3K4 methylation observed in atx 1 mutants suggests that other
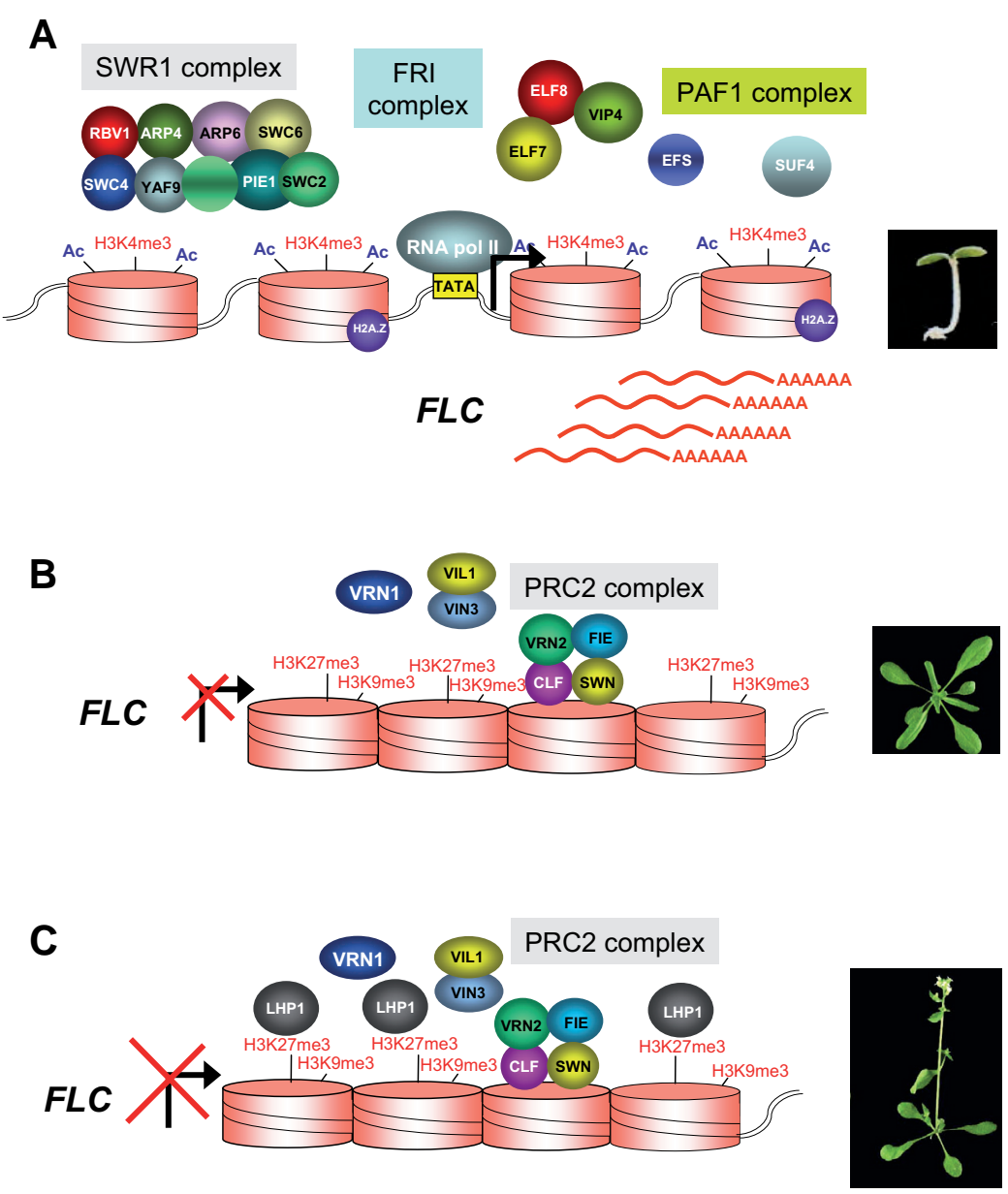

Fig. 2. Hypothetical models for chromatin-dependent regulation of FLOWERING LOCUS C (FLC) expression. FLC chromatin might exist in at least three different configurations: the active state required for the establishment of the winter-annual habit of Arabidopsis (A), the repressed state that occurs under prolonged exposure to cold during the winter season (B), and the stably silenced state (C), where Like Heterochromatin Protein 1 (LHP1) is involved in the maintenance of stable FLC repression by vernalization. In the fall season, components of the SWR1, FRIGIDA (FRI), and Polymerase Associated Factor (PAF) complexes are required to maintain FLC chromatin activated (A). Histone modifications associated with active $\mathrm{FLC}$ such as acetylation of histone $\mathrm{H} 3$ and $\mathrm{H} 4$ and $\mathrm{H} 3 \mathrm{~K} 4 \mathrm{me} 3$ decrease in $\mathrm{FLC}$ chromatin following vernalization, and additionally, the level of repressive marks like H3K9 and H3K27 trimethylation increases. Winter low temperature promotes Vernalization-Insensitive3 (VIN3) (and maybe VIL1) proteins to interact with an Arabidopsis PRC2 complex to epigenetically silence FLC (B). This silencing is maintained by VRN1 and LHP1 together with the VIN3-PRC2 complex (C); LHP1 might contribute to PCG-mediated silencing in a PRC1-like analogous manner. Ac, acetylated lysines of histones $\mathrm{H} 3$ and $\mathrm{H} 4 ; \mathrm{H} 3 \mathrm{~K} 4 \mathrm{me} 3$, trimethylated lysine 4 of histone $\mathrm{H3} ; \mathrm{H} 3 \mathrm{~K} 9 \mathrm{me} 3$, trimethylated lysine 9 of histone $\mathrm{H3} ; \mathrm{H} 3 \mathrm{~K} 27 \mathrm{me}$, trimethylated Iysine 27 of histone H3; H2A.Z, Histone H2 variant; RNA pol II, RNA polymerase II.

Trx proteins could contribute to overall H3K4 methylation levels. In addition, atx 1 mutants show reduced levels of expression of floral homeotic genes repressed by $\mathrm{PcG}$ proteins such as $A G$, $A P 3$ and $P /$, indicating that ATX1 is necessary for proper activation of these genes in developing flowers (Alvarez-Venegas etal., 2003; Saleh et al., 2007). Moreover, ATX1 is required for FLC expression (Pien et al., 2008). Thus, as in animals, plant Trx 
proteins may function in antagonizing the repressor activity of PcG complexes. The mechanism directing both Trx and PcG complexes to the target genes remains essentially unknown and so far no Polycomb or trithorax Responsive Elements (PRE/ TREs) have been identified in plants.

\section{Role of other chromatin remodeling factors}

Chromatin remodeling factors belonging to the SWI/SNF family previously discussed for their role in meristem maintenance are also involved together with PcG and Trx complexes in the control of gene expression during primordia initiation and floral patterning. PICKLE (PKL) encodes an ATP-ase of the CHD3 class containing a CHROMODOMAIN (CHD) and a PLANT HOMEODOMAIN (PHD), two motifs normally found in chromatin remodeling factors, and contributes to the repression of meristem-specific genes in new primordia. $P K L$ is involved in the suppression of embryonic and meristematic characteristics during development, and in leaf primordia PKL cooperates with ASYMMETRIC LEAVES 1 (AS1) and AS2 to repress KNOX genes or their target genes (Ogas et al., 1999; Ori et al., 2000). AS1 contains a SANT motif, also found in SWI3 proteins, which interact with a SWI/SNF chromatin remodeling factor (Sarnowski et al., 2005). Apart from this role in repression of meristemspecific genes, other SWI/SNF proteins play crucial roles in floral patterning. AtBRMis required for proper acquisition of floral organ identity since $\mathrm{brm}$ mutants show severe flower abnormalities including homeotic transformations and reduced expression levels of AP2, AP3, PI and NAC-LIKE, ACTIVATED BY AP3/PI (NAP) (Hurtado et al., 2006). BRM and AtSWI3c show strong interactions, and atswi3c mutants display similar defects to $\mathrm{brm}$ mutant plants, suggesting that both components might act in a common genetic pathway or even are part of the same protein complex during floral homeotic gene activation (Sarnowski et al., 2005; Hurtado et al., 2006; Farrona et al., 2007). swi3dmutants also show defects in floral development although the phenotypic alterations are clearly distinguishable from those present in swi3c mutants, and BRM does not interact with ATSWI3D. SYD is also involved in the repression of the floral transition and floral development (Wagner and Meyerowitz, 2002) and can interact with different SWI3 ATPases. Gene expression profiling has revealed that these two ATPases control the expression of a limited number of genes in different developmental processes, and that they are specific transcriptional co-regulators (Kwon et al., 2005; Kwon et al., 2006). SYD and AtBRM have unique and shared targets and interaction partners, and they have a remarkable degree of regulatory specificity (Sarnowski et al., 2005; Bezhani et al., 2007). Altogether, the emerging picture is starting to suggest that a number of SWI/SNF complexes containing different SWI3 subunits coexist in plants; these different combinations and their interaction with other components provide specificity to regulate different target genes and processes along development.

Chromatin organization in the control of flowering time. A model for epigenetic regulation of gene expression

In Arabidopsis, growth in long days (LD) accelerates flowering, while short days (SD) delay the floral transition. Two major
Arabidopsis growth habits can be distinguished in natural populations: summer annual plants which germinate in the spring and flower in late spring or early summer and winter annual plants which germinate in the fall but will not flower till the next spring (Sung and Amasino, 2006). In most winter-annual plants, the acquisition of competence to flower requires an extended period of cold exposure (vernalization), and the floral repressor gene $F L C$ plays a central role in this adaptive response. The winterannual habit of Arabidopsis is mainly established by the ability of $F R I G I D A$ (FRI) to promote high levels of expression of the floral repressor $F L C$, a MADS-box gene that inhibits the expression of the floral integrators FTand SUPPRESSOR OFOVEREXPRESSION OF CO (SOC1) (Sung and Amasino, 2006; Dennis and Peacock, 2007). Accumulation of the FLC protein prevents plants from flowering, but a prolonged exposure to cold causes FLC repression, which is maintained for the rest of the plant life cycle in a mitotically stable manner (Baurle and Dean, 2006). The regulation of $F L C$ expression and its stable repression in response to winter temperatures involves a number of chromatin remodeling processes that have become a model for epigenetic regulation of gene expression in plants (reviewed in Schmitz and Amasino, 2007; Farrona et al., 2008). Moreover, chromatin remodeling processes are also involved in the negative control of FT, SOC1 or AGL 19 genes during vegetative development and their expression upon flowering induction, reinforcing the role of chromatin dynamics in the control of flowering time (Piñeiro et al., 2003; Takada and Goto, 2003; Bouveret el al., 2006; Germann et al., 2006; Imauzumi and Kay, 2006).

\section{Establishment of the winter-annual habit}

The establishment of the winter-annual habit of Arabidopsis requires high levels of $F L C$ expression during the first growing season in order to block flowering before winter. For that, the $F L C$ switch must be reset to the active state as it passes to the next generation and this resetting, postulated to occur during meiosis (Sheldon et al., 2008), is necessary to perpetuate the vernalization requirement in successive generations (reviewed in Schmitz and Amasino, 2007). The isolation of early flowering mutants in winter annual genetic backgrounds showing reduced levels of $F L C$ expression has led to the identification of genes required to activate $F L C$ at the beginning of the life cycle. These genes encode components of two different putative chromatin remodeling complexes, the PAF1 and the SWR1 complexes (Figure 2A; Table I).

Genes encoding proteins related to components of the yeast transcriptional activating Polymerase Associated Factor 1 (PAF1) complex include early flowering 7 (elf7), elf8 and vernalization independent 4 (vip4) (He et al., 2004; Oh et al., 2004, 2008). In yeasts, this complex interacts with SET1 and SET2 HMTases involved in methylation of H3K4 and H3K36 respectively (Krogan et al., 2003; $\mathrm{Ng}$ et al., 2003). There is a correlation between FLC expression and high levels of $\mathrm{H} 3 \mathrm{~K} 4$ methylation at $F L C$ chromatin (He et al., 2004; Kim et al., 2005; Martin-Trillo et al., 2006). Mutants in the SET domain-histone methyltransferase EARLY FLOWERING IN SHORT DAYS (EFS/SDG8) also flower early and display reduced levels of $F L C$ expression, like PAF1 complex mutants (Kim et al., 2005; Zhao et al., 2005), suggesting that PAF1 complex and EFS may act directly on FLC to maintain high levels of expression. EFS/SDG8 H3 methyltransferase seems to 
antagonize PcG repression of developmental master genes and shows homology to Drosophila TrxG proteins such as Absent, Small and Homeotic Discs 1 (ASH1). Thus, this SET domain protein has been proposed to perform TrxG proteins functions in plants. Consistently, two different reports have provided evidence that EFS/SDG8 is required for high levels of either $\mathrm{H} 3 \mathrm{~K} 4 \mathrm{me} 3$ or H3K36me2 in the region of FLC (Kim et al., 2005; Zhao et al., 2005). One additional factor, SUPPRESSOR OF FRIGIDA 4 (SUF4), could function as an intermediate to recruit the PAF1 complex to FLC chromatin (Kim and Michaels, 2006; Kim et al., 2006).

Genes encoding putative orthologues of the yeast SWR1 complex include EARLY IN SHORT DAYS1/SUF3/ ACTIN RELATED PROTEIN 6 (ESD1/SUF3/ARP6) (Choi et al., 2005; Deal et al., 2005; Martin-Trillo et al., 2006), PHOTOPERIOD INDEPENDENTEARL Y FLOWERING 1 (PIE1), (Noh etal., 2003), and AtSWC6/SEF1 (SERRATED AND EARL Y FLOWERING 1)(Choi et al., 2007; March-Diaz et al., 2007; Lazaro et al., 2008). The SWR1 complex in yeast catalyzes the replacement of nucleosomal $\mathrm{H} 2 \mathrm{~A}$ by the H2A.Z variant, ensuring full activation of underlying genes. This $\mathrm{H} 2 \mathrm{~A}$. $Z$ histone variant has recently been identified within FLC chromatin (Deal et al., 2007) and loss of H2A.Z from FLC chromatin in esd1/suf3/arp6 and pie1 mutants results in reduced $F L C$ expression and premature flowering. In addition, H2A.Z interacts with both PIE1 and AtSWC2, and knockdown of the H2A.Z genes by RNA interference or artificial microRNA (miRNA) caused a phenotype similar to that of esd1/suf3/arp6 mutants (Choi et al., 2007). These observations support the existence of a SWR1-like complex in plants that is targeted to different loci including $F L C$, and show that the presence of the $\mathrm{H} 2 \mathrm{~A}$.Z histone variant in the chromatin of specific genes enhance their transcriptional activation in plants. The fact that H2A.Z remains associated with chromatin throughout mitosis suggests that it may serve as an epigenetic memory function marking active genes and poising silenced genes for reactivation (Deal et al., 2007).

\section{FLC repression, the vernalised state}

Under prolonged exposure to cold during the winter season, FLCexpression is progressively repressed. This state of $F L C$ that will later facilitate flowering induction in spring is maintained for the rest of the plant life cycle in a mitotically stable manner, even after cold exposure ends, suggesting the involvement of a mechanism conferring cellular memory for remembering winter (Sung and Amasino, 2006). Recent studies have confirmed that vernalization of Arabidopsis plants causes a number of changes in the array of histone modifications present in the FLClocus, providing further evidence for the involvement of chromatin remodeling processes in the mitotic stability of the vernalized state (Figure 2B). Histone modifications associated with active genes such as acetylation of histone $\mathrm{H} 3$ and $\mathrm{H} 4$ and $\mathrm{H} 3 \mathrm{~K} 4$ me decrease in FLC chromatin following vernalization (Sung and Amasino, 2004; Sung et al., 2006a). Additionally, the level of repressive marks like H3K9 and H3K27 di and trimethylation increases during vernalization (Bastow etal., 2004; Sung and Amasino, 2004; Sung etal., 2006a). The involvement of PcG proteins in FLC repression during vernalization was first revealed by the molecular characterization of VRN2 that encodes a homologue of the PRC2 component Su(z)12 (Gendall et al., 2001). Recent results have shown that a PRC2 complex containing VRN2 also includes other PcG homologues such as FIE and the $E(z)$ homologues CLF and SWN (Wood et al., 2006; De Lucia et al., 2008) (Figure 2B). This complex is probably responsible for methylation of $\mathrm{H} 3 \mathrm{~K} 27$ in the FLC locus (Bastow et al., 2004; Sung and Amasino, 2004). However, methylation of H3K27 mediated by the VRN2-PRC2 complex is not sufficient to maintain stable $F L C$ repression after vernalization. Methylated $\mathrm{H} 3 \mathrm{~K} 9$ also appears to be an important histone mark during vernalization because vrn1 mutants lack $\mathrm{H} 3 \mathrm{~K} 9$ methylation but not $\mathrm{H} 3 \mathrm{~K} 27 \mathrm{me} 3$ in the chromatin of $F L C$, and $F L C$ repression is not stably maintained in these plants. This observation is consistent with the involvement of VRN1 in H3K9 methylation after the VRN2-complex methylates H3K27 (Bastow et al., 2004; Sung and Amasino, 2004). The PHD-containing protein VERNALIZATION INSENSITIVE 3 (VIN3) is also necessary to accelerate flowering in response to prolonged cold exposure (Sung and Amasino, 2004). VIN3 mRNA accumulates only after a period of cold sufficient to trigger vernalization and its expression domain overlaps with that of $F L C$. VIN3 appears to be required for histone deacetylation in the $F L C$ region following vernalization (Sung and Amasino, 2004). None of the repressive marks associated to vernalization are present in vin3 mutants, suggesting that VIN3-mediated deacetylation of FLC-chromatin may facilitate histone methylation by a VRN2-PRC2 or other histone methylation complexes.

The mechanism by which high expression chromatin marks such as H3K4me3 are reduced by cold exposure remains obscure, but specific demethylases may be involved. Recent results have shown that the PHD domain can bind trimethylated $\mathrm{H} 3 \mathrm{~K} 4$ and bring chromatin remodeling complexes to target genes and modulate their level of expression (Becker, 2006; Mellor, 2006). This raises the possibility that recognition of trimethylated H3K4 by the PHD finger of VIN3 could contribute to the recruitment or modulate the activity of a silencing chromatin remodeling complex or complexes. A VIN3-interacting protein referred to as VIN3LIKE1 (VIL1)/VRN5 is also required for a proper vernalization response (Sung et al., 2006a; Greb et al., 2007) (Figure 2B). Similarly to vin3, vil1 mutations result in a vernalization-insensitive phenotype and absence of repressive histone modifications in FLC (Sung et al., 2006a; Greb et al., 2007). VIN3 and VIL1 belong to a small gene family, and the possible role of the other members in the vernalization response is still unknown. Thus vernalization appears to require a chromatin remodeling complex that contains at least two PHD finger proteins. Recently, VIN3, VIL1 and VIL2/VEL1 were found as part of the VRN2-PRC2 complex mentioned above, that is likely to be involved in the initial stages of vernalization-mediated FLC repression (Wood et al., 2006; De Lucia et al., 2008). The abundance of the complex increases during vernalization and declines after plants are returned to warm temperatures. VRN2 associates throughout the FLC locus independently of the cold, whereas association of VIL1 to a specific domain in FLC intron 1 is dependent on cold and VIN3 (De Lucia et al., 2008). The VRN2-VIN3 complex may bring histone deacetylase and histone methyltransferase activities together at FLC chromatin, providing a coordinated mechanism for the epigenetic modifications associated with the vernalizationmediated repression of $F L C$ gene. Vernalization has been proposed to be a two-step process, with an initial downregulation of FLCfollowed by maintenance of the repressed state by a Polycomb 
complex. In fact, the deletion of a sequence of the FLCfirst intron referred to as vernalization response element (VRE), required for maintenance of the repressed state, does not prevent the initial repression of $F L C$ by cold (Sung et al., 2006b). Thus, the initial response maybe separable and is mediated by other sequence elements residing in the promoter or along the first intron of the gene. Recently it has been suggested that the VRN2-containing PRC2 complex determines the extent of downregulation but not the maintenance of $F L C$ repression (Sheldon et al., 2006). In addition, a reverse genetics approach has revealed that LHP1 is involved in the maintenance of stable FLC repression by vernalization (Mylne et al., 2006; Sung et al., 2006b) (Figure 2C) and is associated with regions methylated at H3K9 of FLC chromatin during vernalization, including the region encompassing the VRE (Sung et al., 2006b). Moreover, LHP1 is required for maintaining increased $\mathrm{H} 3 \mathrm{~K} 9$ methylation at $F L C$, but not for the initiation of this methylation during cold exposure (Sung et al., 2006b), suggesting that in addition to VRN2-PRC2 complex, there might be two different histone methylating components involved in the vernalization response.

In spring habit (summer annual) plants, $F L C$ is frequently silenced as the result of the lack of function of $F R /$ but also with the contribution of other factors involved in chromatin remodeling which participate in the negative regulation of FLC expression. These include proteins such as FVE and FLOWERING LOCUS D (FLD) that show similarity to mammalian chromatin remodeling factors. Both factors are components of the so-called autonomous floral promotion pathway, defined on the basis of the phenotype of Arabidopsis late flowering mutants responsive to both photoperiod and vernalization (for reviews see Ausin et al., 2005; Baurle and Dean, 2006; Schmitz and Amasino, 2007). The homologue of FVE in animals is found in Nucleosome Remodeling Factor (NuRF) and HDAC complexes and is likely to function as a histone chaperone (Ausin et al., 2004; Kim et al., 2004). FLD is highly homologous to human KIAA0601/Lysine Demethylase 1 (LSD1) also present in HDAC complexes (Lee et al., 2006b). LSD1 is a polyamine oxidase (PAO) that can demethylate H3K4 (Shi et al., 2004). Consistent with the nature of these proteins, the increased expression of FLC in fve and fldmutants is correlated with hyperacetylation of histones $\mathrm{H} 3$ and $\mathrm{H} 4$ ( $\mathrm{He}$ et al., 2003; Ausin et al., 2004), a modification associated to transcriptionally active chromatin conformations.

Besides these classical members of the autonomous pathway, new components of chromatin remodeling complexes that participate in $F L C$ repression are beginning to emerge. That is the case of AtSWP1/LDL1, another member of the family of PAO/LSD1 proteins found in Arabidopsis, and therefore a homologue of FLD. AtSWP1 can interact with a plant-specific $\mathrm{C} 2 \mathrm{H} 2$ zinc finger-SET domain protein named AtCZS. Knock-out (KO) mutations in the genes encoding any of these two proteins result in hyperacetylation of histone $\mathrm{H} 4$ and reduced methylation of $\mathrm{H} 3 \mathrm{~K} 9$ and $\mathrm{H} 3 \mathrm{~K} 27$ in the genomic region of $F L C$. Consistent with these observations swp 1 and $c z s$ mutants show increased $F L C$ expression and a moderate delay in flowering (Krichevsky et al., 2007). Recently, AtSWP1/ LDL1 and its homolog LDL2 have also been shown to reduce the levels of H3K4 methylation in the chromatin of FLC and FWA (Jiang et al., 2007). These results suggest that AtSWP1/LDL2 and AtCZS represent components of a plant specific repressor complex involved in the fine tuning of $F L C$ expression. Confirming the central role of chromatin remodeling processes in the regulation of $F L C$, two additional chromatin associated factors have been recently proposed as components of the autonomous pathway: RELATIVE OF EARLY FLOWERING 6 (REF6) and SHK1 BINDING PROTEIN 1(SKB1). REFG encodes a member of a large family of Arabidopsis jumonji-containing factors related to mammalian proteins involved in the demethylation of lysine residues in different positions of histone $\mathrm{H} 3$. ref6 6 mutants display a modest delay in flowering as compared to other autonomous pathway mutants, although this late flowering is suppressed by $\mathrm{flC}$ mutations (Noh et al., 2004). SKB1 is a homolog of a human arginine methylase (PRMT5) that catalyses the symmetric dimethylation of H4R3 (H4R3sme2) and binds the FLCpromoter; skb1 loss-of-function mutations result in upregulation of FLC and late flowering that can be reversed by vernalization. Furthermore skb1 mutants show decreased H4R3sme2 in regulatory regions of $F L C$, suggesting that this histone covalent modification is also required for the induction of flowering mediated by $F L C$ repression (Pei et al., 2007; Wang et al., 2007; Schmitz et al., 2008).

Finally, small RNA-mediated chromatin silencing also appears to be required for the regulation of $F L C$, and $3^{\prime}$ end regions of this locus constitute targets of si-RNAs and are enriched in H3K9me2 in a DICER dependent way (Schmitz et al., 2007; Swiezewski et al., 2007). All these observations highlight the importance of chromatin remodeling processes in the regulation of the central Arabidopsis floral repressor $F L C$.

\section{Regulation of flowering signal integrator genes by chromatin remodeling}

$F L C$ epigenetic regulation is the best known example of the role of chromatin remodeling in the control of flowering time, but it is not the only one (Farrona et al., 2008). AGAMOUS-LIKE19 (AGL 19) is another MADS box gene recently shown to be controlled by mechanisms involving chromatin remodeling processes mediated by PcG proteins (Alexander and Hennig, 2008). This floral activator acts to promote flowering in response to prolonged cold exposure (Schonrock et al., 2006). In contrast to FLC mediated repression of flowering, this, so far, poorly understood pathway does not require $S O C 1$ to promote the floral transition. In the absence of cold, the expression of $A G L 19$ is maintained at very low levels and the chromatin of this locus is heavily enriched in H3K27me3 repressive marks. Plant PRC2 polycomb proteins such as MSI1, CLF and EMF2, but not VRN2, appear to be necessary for those high levels of H3K27me3 and AGL 19repression in the absence of cold. Following vernalization, the levels of H3K27me3 decrease in the promoter and ATG regions of AGL 19 relieving its repression by a mechanism that requires VIN3. The induction of $A G L 19$ results in activation of floral meristem identity genes $\angle E A F Y(\angle F Y)$ and $A P 1$ and subsequent flowering (Schonrock et al., 2006).

Silencing of the SWI/SNF chromatin remodeling ATPase gene AtBRM using RNA interference strategies revealed that this protein is involved in the regulation of different aspects of plant development, including floral transition (Farrona et al., 2004). $A t B R M$ silenced plants flower earlier than wild-type plants and show increased levels of CONSTANS (CO), FT and SOC1 expression under non-inductive photoperiodic conditions, suggesting that $A t B R M$ contributes to the repression of these genes that participate in the long day promotion pathway (Imaizumi and 

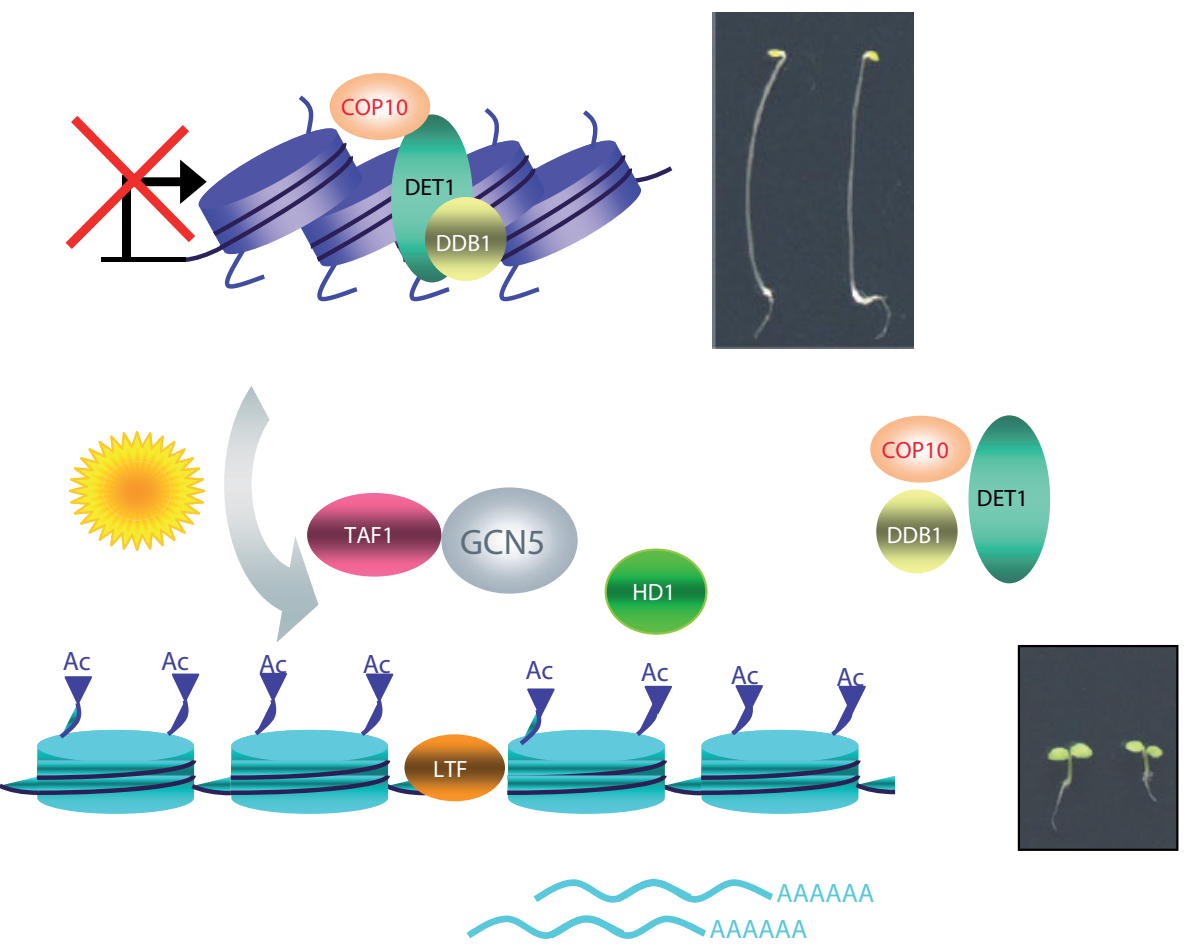

Fig. 3. Chromatin remodeling plays a central role in the control of light-responsive gene expression and photomorphogenesis. In darkness, seedlings follow a skotomorphogenesis developmental pathway generating a long hypocotyl phenotype. Under these conditions, the $D E T 1 / D D B 1 / C O P 10$ complex may bind to non-acetylated H2B (and maybe other histones) to repress the expression of light-responsive genes. In response to light, the DET1/DDB1/COP10 complex might recruit histone acetyltransferase (HAT) activities, such as TAF1 and GCN5, causing acetylation of histones $\mathrm{H} 3$ and $\mathrm{H} 4$ (and maybe others) at the promoter of light-inducible genes and the release of the DET1/DDB1/COP10 complex. This is accompanied by changes in nucleosome accessibility at the promoter region and correlates with light-induced transcription mediated by specific light-responsive transcription factors (LTF). HD1 may play an opposing role to GCN5 to fine-tune and balance light regulation of gene expression during photomorphogenesis.

Kay, 2006). Modifications of chromatin structure are also likely involved in the regulation of the expression of floral integrator $F T$. At least a PRC2-like complex containing CLF, EMF2 and FIE (Jiang et al., 2008), as well as two additional factors involved in chromatin remodeling processes are required to repress $F T$ expression, LHP1/ TFL2 and EARLY BOLTING IN SHORT DAYS (EBS) (Piñeiro et al., 2003; Takada and Goto, 2003). Mutations in the genes encoding any of these proteins cause early flowering and upregulation of $F T$, especially under non-inductive photoperiods, suggesting that these proteins are required in the establishment of a non-active chromatin conformation at the FT locus under non inductive short day photoperiods (reviewed in Imaizumi and Kay, 2006). As discussed above, LHP1/TFL2 is involved in the silencing of euchromatic genes related to developmental processes; in addition to its role in maintaining vernalizationinduced silencing of $F L C$, LHP1 is targeted to the promoter and transcribed regions of $F T$ to repress its expression, and also participates in the repression of vegetative expression of floral organ identity genes (Gaudin et al., 2001; Kotake et al., 2003; Takada and Goto, 2003; Nakahigashi et al., 2005; Libault et al., 2005; Germann et al., 2006). EBS is a plant-specific nuclear protein that contains a BAH (BromoAdjacent Homology) and a
PHD Zn finger motif (Piñeiro et al., 2003); both types of domain are present in chromatin remodeling factors, and as for LHP1/ TFL2, the role of EBS in the regulation of plant development is not restricted to the floral transition. ebs mutants show pleiotropic developmental alterations including defects in the expression of floral organ identity genes as well as a reduction in seed dormancy, which suggests a role for chromatin organization in the repression of germination during the dormancy period (GomezMena et al., 2001; Liu et al., 2007).

Confirming the central role of chromatin remodeling in the control of flowering time, plants with reduced levels of $M S / 1$ show late flowering and delayed induction of the floral integrator SOC1. MSI1-mediated activation of SOC1 is independent of FLC and is correlated with increased levels of histone modifications such as $\mathrm{K} 4 \mathrm{H} 3 \mathrm{me} 2$ and $\mathrm{H} 3 \mathrm{~K} 9$ acetylation in the SOC1locus; these histone marks are associated to actively transcribed chromatin, suggesting that epigenetic mechanisms operate in the genomic region of this floral activator during the induction of flowering (Bouveret et al., 2006).

\section{Chromatin-mediated responses to environmental cues}

As discussed above, different chromatin remodeling mechanisms in plants generate epigenetic modifications which provide a mechanism for the stable propagation of gene activity states from one cell generation to the next. These mechanisms provide a cell memory for past environmental events such as vernalization or stabilize specific developmental phases and patterns of differentiation. Chromatin remodeling mechanisms also participate in the regulation of gene expression which takes place in differentiated cells in response to environmental cues either when they represent expected regular variations, such as light-dark cycles, or unpredictable stress conditions.

\section{Chromatin remodeling processes during photomorphogen- esis}

Many of the physiological modifications induced by light are the result of changes in gene expression (Jiao et al., 2007). In addition to the regulation mediated by transcription factors that bind a number of defined light-responsive regulatory elements, chromatin remodeling processes play a central role in the control of light-responsive gene expression and photomorphogenesis. Increased acetylation of histones $\mathrm{H} 3$ and $\mathrm{H} 4$ at the promoter of a pea plastocyanin (PetE) gene correlates with light-induced transcription (Chua et al., 2001), and is accompanied by changes in nucleosome accessibility at the promoter region. Furthermore, transcriptional enhancers associated with the nuclear matrix seem to trigger the light-induced acetylation of histones in promoter and nearby coding regions to activate transcription (Chua 
et al., 2003). More recently a pivotal role of Arabidopsis histone acetyl transferases TAF1 and GCN5 and deacetylases such as HD1 in the control of histone acetylation at several light-responsive genes has been established (Bertrand etal., 2005; Benhamed et al., 2006). Mutants of TAF1 displayed reduced $\mathrm{H} 3$ acetylation in light-responsive promoters, altered expression of about $9 \%$ of genes in young leaves and developmental abnormalities (Bertrand et al., 2005). Furthermore, loss of function mutations of the GCN5 HAT resulted in a long-hypocotyl phenotype and reduced lightinducible gene expression, whereas mutants of HD1 displayed opposite effects. A detailed analysis revealed that TAF1, GCN5 and HD1 have distinct and specific effects on the acetylation of particular lysine residues present in $\mathrm{H} 3$ and $\mathrm{H} 4$ histones of promoter regions required for light regulation of gene expression (Benhamed et al., 2006) (Figure 3; Table I). Indeed, variations in histone modifications have been demonstrated as important physiological components of plant responses to changing light environments (Guo et al., 2008).

Arabidopsis DE-ETIOLATED1 (DET/) also seems to control light regulated gene expression through chromatin remodeling. det1 mutants show photomorphogenesis in the dark and nearly half of the genes induced by light in the wild type show enhanced expression in the det1 mutant (Schroeder et al., 2002). In contrast to the enhanced expression observed in dark-grown seedlings and roots, det 1 mutants show reduced expression of $C A B$ genes in light-grown leaves. DET1 is part of a protein complex (CDD) containing the homolog of UV-Damaged DNA Binding Protein 1 (DDB1), a protein that interacts with HAT complexes (Schroeder et al., 2002), and COP10 (Yanagawa, et al., 2004). DDB1 binds HAT complexes in other species, and therefore a suggestive possibility is that in darkness DET1 binds H2B and DDB1 to repress transcription. In response to light, the DET1/DDB1 complex might recruit HAT activities, causing acetylation of H2B (and maybe other histones) and the release of the DET1/DDB1 complex to promote transcription (Benvenuto et al., 2002; Schroeder et al., 2002). Binding of DET1 to specific promoter sequences to induce or repress gene transcription could be mediated by transcription factors like CCA1 and HY5. The dual activity of DET1, working as a repressor and promoting transcription via recruitment of HAT complexes would be consistent with the contrasting effects of det1 mutations on gene expression. Thus, it appears that chromatin modifications are convergent points in light regulated transcription (Figure 3) and are likely to act as downstream switches of multiple photoreceptors in regulatory networks. Consistent with the role of light in chromatin remodeling processes, inductive photoperiods cause a CRY2 dependent extensive reduction in chromocenters of rosette leaves chromatin prior to bolting, which is followed by a recovery of the heterochromatin domains after elongation of the floral stem. A blue light triggered decondensation of chromatin in gene-rich regions suggests the existence of a light-signalling pathway mediating large scale chromatin modulation (Tessadori et al., 2007).

\section{Signaling to the circadian clock: plasticity by chromatin remodeling}

Circadian rhythms are driven by endogenous biological clocks that confer a 24-hour rhythm on many biochemical and physiological processes and are also relevant on seasonal rhythms, such as flowering (Imaizumi and Kay, 2006). In higher plants, as in animals and fungi, endogenous biological clocks are based on autoregulatory negative-feedback loops, which are synchronized by entraining stimuli, in particular light and temperature. The complex program of gene expression that characterizes circadian physiology involves dynamic changes in chromatin structure that ensure the proper timing and extent of circadian regulation. In this way, the animal transcription factor CLOCK was recently found to have intrinsic HAT activity (Doi et al., 2006) and transcriptional activation of clock-controlled genes by CLOCK-BMAL1 has been shown to be coupled to circadian changes in histone acetylation at their promoters (Etchegaray et al., 2003; Ripperger and Schibler, 2006). Indeed, CLOCK-mediated acetylation of BMAL1 controls circadian function (Hirayama et al., 2007). Thus transcriptionpermissive chromatin states are dynamically established in a circadian-time-specific manner. A direct connection between chromatin remodeling and the plant circadian clock has also been recently reported. The circadian induction of the Arabidopsis clock component TIMING OF CAB EXPRESSION 1 (TOC1) is accompanied by cycles of histone acetylation that favor a transcriptionally active chromatin conformation at the TOC1 locus. In contrast, CCA1-mediated repression of TOC1 at dawn is facilitated by HDAC activities that promote the switch to an inactive chromatin structure (Perales and Mas, 2007; Stratmann and Mas, 2008).

\section{Cold acclimation}

Gene expression events underlying cold acclimation of plants to low temperatures, whereby exposure to low non-freezing temperatures results in protection from subsequent exposure to freezing temperatures, may be also regulated by chromatin remodeling (Vlachonasios et al., 2003; Mao et al., 2006). In Arabidopsis, a family of transcription factors known as CBF1, CBF2 and CBF3 are induced by low temperatures and direct the expression of a set of cold-regulated (COR) genes. Different reports have identified coactivator proteins such as GCN5HAT and $A D A 2$ homologs ( $A D A 2 a$ and $A D A 2 b$ ) that interact with CBF1 and could be involved in the stimulation of cold-regulated gene expression by CBF1 (Stockinger et al., 2001; Vlachonasios et al., 2003). The yeast homologous proteins are components of HAT complexes (Lee et al., 2007), suggesting that CBF1 might stimulate transcription through the recruitment of the ADA/SAGA-like complexes to the promoters of its target genes (Stockinger et al., 2001). Indeed, cold-regulated gene expression was diminished in gcn5-1 and ada2b-1 mutant plants (Vlachonasios et al., 2003). Furthermore, FVE, an MSI-like protein involved in the deacetylation of the $F L C$ locus, has also been identified as a negative regulator of the CBF pathway (Kim et al., 2004). Thus, it is tempting to speculate that the induction of genes that respond to cold is mediated by HAT activities that are antagonized by HDAC FVEcontaining complexes, and therefore histone acetylation mediates transcriptional activation by CBF proteins during cold acclimation in Arabidopsis. HOS15, a component of a repressor protein complex involved in histone deacetylation is also required for cold tolerance in Arabidopsis (Zhu et al., 2008).

\section{Chromatin remodeling in response to stress}

Responses to abiotic stress require the modulation of gene expression, which is also mediated by the alteration of chromatin 
structure (Arnholdt-Schmitt, 2004). One basic response of plants to environmental stress is the establishment of a temporary growth arrest that allows adaptation to adverse conditions and AtCHR12 SNF2/Brahma-type ATPase seem to play a vital role in mediating this response (Mlynarova et al., 2007; Table I). Exposing an AtCHR12 overexpressing mutant to stress conditions leads to rapid growth arrest of normally active primary buds, as well as to reduced growth of the primary stem. In contrast, the AtCHR12 KO mutant shows less growth arrest than the wild-type when exposed to moderate stress. Without stress, AtCHR12KO mutant plants are indistinguishable from the wild-type, and the growth arrest response seems to depend on the severity of the stress applied. Modulation of AtCHR12 expression also correlates with changes in expression of dormancy-associated genes. This is in agreement with the participation of AtCHR12 in priming plants for growth arrest in the case of stress conditions. By priming their growth response, plants do not repress growth before they actually perceive stress, permitting flexible modulation of growth in adverse and/or otherwise limiting environments. Growth arrest upon stress is thought to be advantageous for plants (Achard et al., 2006) since slower growth might allow plants to redirect resources to overcome or temporarily cope with stress. Apart from this basic growth retardation response, chromatin-remodeling would likely be involved in transcriptional responses to any environmental factor. This is the case of the maize response to UV-B radiation where RNAi transgenic plants with lower expression of four chromatin-associated genes exhibited hypersensitivity to UV-B and altered UV-B regulation of selected genes (Casati et al., 2006), suggesting that genes involved in chromatin remodeling are crucial for UV-B acclimation. Moreover, H3 and H4 histone acetylation and chromatin remodeling are required for proper UV-B dependent activation of genes in maize (Casati etal., 2008). Recently, alterations of lysine modifications on histone H3 $\mathrm{N}$-tail and patterns of nucleosome changes under drought stress have been reported (Kim et al., 2008).

\section{Concluding remarks}

The molecular genetic analysis of plant development has reached to the level of epigenetic modification of chromatin. Chromatin structure, determined by a large number of factors which provide epigenetic histone marks, strongly influence the transcriptional activity of master regulatory genes controlling the development of organs and tissues as well as response to environmental cues such as light and temperature. Proper inheritance of chromatin modifications throughout cell division ensures the maintenance of transcriptional states in daughter cells, the proper establishment of cell fates and correct response to changes in the environmental stimuli.

Chromatin remodeling mechanisms and complexes are widely conserved among plants, animals and yeast, indicating that ancient mechanisms evolved in a common eukaryote ancestor. However, the continuous post-embryonic development of plants and its plasticity modulated by environmental cues suggest that chromatin modification must have a higher flexibility in plants than in animals. This flexibility requirement could be responsible for the higher redundancy of complex components observed in plants, allowing the viability of loss-of-function mutants.

Genomic advances in plants such the sequencing of a growing number of genomes, the feasibility of high-throughput genomic, transcriptomic and proteomic analyses and the wide range of reverse genetic tools available are allowing the identification of complete families of plant chromatin modifier factors, making it possible to elucidate the nature of chromatin complexes and facilitating the study of their effect in the transcriptional activity of key regulatory loci. These approaches should provide important insights on how chromatin modifications and epigenetic marks are established and maintained, how chromatin factors interact with each other and how different combinatorial chromatin complexes directly influence the developmental plasticity of plants.

\section{Acknowledgements}

The authors apologise to those researchers whose work has not been included due to space limitations. The authors research activities are funded by the Spanish Ministerio de Educación y Ciencia (Grants BIO200500251 to JAJ, BIO2004-00494 to MP, BIO2005-07612 to JMZ, BIO200500570 and GEN2003-20227-C02-02 to PC, and CSD2007-00057 to JAJ, $M P$ and $P C$ ).

\section{References}

ACHARD P, CHENG H, DE GRAUWE L, DECAT J, SCHOUTTETEN H, MORITZ T, VAN DER STRAETEN D, PENG J, and HARBERD NP. (2006). Integration of plant responses to environmentally activated phytohormonal signals. Science 311:91-94.

ALEXANDRE, C.M. and HENNIG, L. (2008). FLC or not FLC. the other side of vernalization. J EXp Bot. 59:1127-1135.

ALVAREZ-VENEGAS, R., PIEN, S., SADDER, M., WITMER, X., GROSSNIKLAUS, U., and AVRAMOVA, Z. (2003). ATX-1, an Arabidopsis homolog of trithorax, activates flower homeotic genes. Curr. Biol. 13: 627-637.

ARNHOLDT-SCHMITT B. (2004). Stress-induced cell reprogramming. A role for global genome regulation? Plant Physiol. 136:2579-2586.

AUSIN, I., ALONSO-BLANCO, C., and MARTINEZ-ZAPATER, J.M. (2005). Environmental regulation of flowering. Int J Dev Bio/49: 689-705.

AUSIN, I., ALONSO-BLANCO, C., JARILLO, J.A., RUIZ-GARCIA, L., and MARTINEZ-ZAPATER, J.M. (2004). Regulation of flowering time by FVE, a retinoblastoma-associated protein. Nat. Genet. 36: 162-166.

BASTOW, R., MYLNE, J.S., LISTER, C., LIPPMAN, Z., MARTIENSSEN, R.A., and DEAN, C. (2004). Vernalization requires epigenetic silencing of FLC by histone methylation. Nature 427: 164-167.

BÄURLE I. and DEAN C.(2006). The timing of developmental transitions in plants. 125:655-664

BECKER, P. B.(2006). Gene regulation: a finger on the mark. Nature 442: 31-32

BENHAMED, M., BERTRAND, C., SERVET, C., and ZHOU, D.X. (2006). Arabidopsis GCN5, HD1, and TAF1/HAF2 interact to regulate histone acetylation required for light-responsive gene expression. Plant Cel/18: 2893-2903.

BENVENUtO, G., FORMIGGINI, F., LAFLAMME, P., MALAKHOV, M., and BOWLER, C. (2002). The photomorphogenesis regulator DET1 binds the amino-terminal tail of histone H2B in a nucleosome context. Curr. Biol. 12: 15291534.

BERTRAND, C., BENHAMED, M., LI, Y.F., AYADI, M., LEMONNIER, G., RENOU, J.P., DELARUE, M., and ZHOU, D.X. (2005). Arabidopsis HAF2 gene encoding TATA-binding protein (TBP)-associated factor TAF1, is required to integrate light signals to regulate gene expression and growth. J. Biol. Chem. 280: 14651473.

BEZHANI, S., WINTER, C., HERSHMAN, S., WAGNER, J.D., KENNEDY, J.F., KWON, C.S., PFLUGER, J., SU, Y., and WAGNER, D. (2007). Unique, Shared, and Redundant Roles for the Arabidopsis SWI/SNF Chromatin Remodeling ATPases BRAHMA and SPLAYED. Plant Cel/19: 403-416.

BOUVERET, R., SCHONROCK, N., GRUISSEM, W., and HENNIG, L. (2006). Regulation of flowering time by Arabidopsis MSI1. Development 133: 16931702.

BOYER, L.A., PLATH, K., ZEITLINGER, J., BRAMBRINK, T., MEDEIROS, L.A., 
LEE, T.I., LEVINE, S.S., WERNIG, M., TAJONAR, A., RAY, M.K., BELL, G.W., OTTE, A.P., VIDAL, M., GIFFORD, D.K., YOUNG, R.A., and JAENISCH, R. (2006). Polycomb complexes repress developmental regulators in murine embryonic stem cells. Nature 441: 349-353.

CALONJE, M., and SUNG, Z.R. (2006). Complexity beneath the silence. Curr. Opin. Plant Biol. 9: 530-537.

CARROZZA, M.J., UTLEY, R.T., WORKMAN, J.L., and COTE, J. (2003). The diverse functions of histone acetyltransferase complexes. Trends Genet. 19: 321-329.

CASATI, P., CAMPI, M., CHU, F., SUZUKI, N., MALTBY, D., GUAN, S., BURLINGAME, A.L. and WALBOT, V. (2008). Histone acetylation and chromatin remodeling are required for UV-B-dependent transcriptional activation of regulated genes in maize. Plant Cel/20: 827-842.

CASATI P., STAPLETON A.E., BLUM J.E., and WALBOT V. (2006). Genome-wide analysis of high-altitude maize and gene knockdown stocks implicates chromatin remodeling proteins in response to UV-B. Plant J. 46: 613-627.

CHANVIVATTANA, Y., BISHOPP, A., SCHUBERT, D., STOCK, C., MOON, Y.H., SUNG, Z.R., and GOODRICH, J. (2004). Interaction of Polycomb-group proteins controlling flowering in Arabidopsis. Development 131: 5263-5276.

CHOI, K., PARK, C., LEE, J., OH, M., NOH, B., and LEE, I. (2007). Arabidopsis homologs of components of the SWR1 complex regulate flowering and plant development. Development 134: 1931-1941.

CHOI, K., KIM, S., KIM, S.Y., KIM, M., HYUN, Y., LEE, H., CHOE, S., KIM, S.G., MICHAELS, S., and LEE, I. (2005). SUPPRESSOR OF FRIGIDA3 encodes a nuclear ACTIN-RELATED PROTEIN6 required for floral repression in Arabidopsis. Plant Cel/17: 2647-2660.

CHUA, Y.L., BROWN, A.P., and GRAY, J.C. (2001). Targeted histone acetylation and altered nuclease accessibility over short regions of the pea plastocyanin gene. Plant Cel/13: 599-612.

CHUA, Y.L., WATSON, L.A., and GRAY, J.C. (2003). The transcriptional enhancer of the pea plastocyanin gene associates with the nuclear matrix and regulates gene expression through histone acetylation. Plant Cel/15: 1468-1479.

DE LUCIA, F., CREVILLEN, P., JONES, A.M., GREB, T. and DEAN, C.A. (2008). PHD-polycomb repressive complex 2 triggers the epigenetic silencing of $F L C$ during vernalization. Proc Nat/ Acad Sci USA. 105: 16831-16836.

DEAL, R.B., KANDASAMY, M.K., MCKINNEY, E.C., and MEAGHER, R.B. (2005). The nuclear actin-related protein ARP6 is a pleiotropic developmental regulator required for the maintenance of FLOWERING LOCUS C expression and repression of flowering in Arabidopsis. Plant Cel/ 17: 2633-2646.

DEAL, R.B., TOPP, C.N., MCKINNEY, E.C., and MEAGHER, R.B. (2007). Repression of flowering in Arabidopsis requires activation of FLOWERING LOCUSC expression by the histone variant H2A.Z. Plant Cel/19: 74-83.

DENNIS, E.S. and PEACOCK, W.J. (2007). Epigenetic regulation of flowering. Curr. Opin. Plant Biol. 10: 520-527.

DOI, M., HIRAYAMA, J., and SASSONE-CORSI, P. (2006). Circadian regulator CLOCK is a histone acetyltransferase. Cel/125: 497-508.

ESHED, Y., BAUM, S.F., and BOWMAN, J.L. (1999). Distinct mechanisms promote polarity establishment in carpels of Arabidopsis. Cel/99: 199-209.

ETCHEGARAY, J.P., LEE, C., WADE, P.A., and REPPERT, S.M. (2003). Rhythmic histone acetylation underlies transcription in the mammalian circadian clock. Nature 421: 177-182.

EXNER, V. and HENNIG, L. (2008). Chromatin rearrangements in development. Curr. Opin. Plant Biol. 11: 64-69.

FARRONA, S., COUPLAND, G. and TURCK, F. (2008). The impact of chromatin regulation on the floral transition. Semin Cel/ Dev Biol. 19: 560-573.

FARRONA, S., HURTADO, L. and REYES, J.C. (2007). A nucleosome interaction module is required for normal function of Arabidopsis thaliana BRAHMA. JMOl Biol. 373: 240-250.

FARRONA, S., HURTADO, L., BOWMAN, J.L., and REYES, J.C. (2004). The Arabidopsis thaliana SNF2 homolog AtBRM controls shoot development and flowering. Development 131: 4965-4975.

GAUDIN, V., LIBAULT, M., POUTEAU, S., JUUL, T., ZHAO, G., LEFEBVRE, D., and GRANDJEAN, O. (2001). Mutations in LIKE HETEROCHROMATIN PROTEIN 1 affect flowering time and plant architecture in Arabidopsis. Development 128: 4847-4858.
GENDALL AR, LEVY YY, WILSON A, DEAN C. (2001). The VERNALIZATION 2 gene mediates the epigenetic regulation of vernalization in Arabidopsis. Cell. $107,525-535$

GERMANN, S., JUUL-JENSEN, T., LETARNEC, B., and GAUDIN, V. (2006). DamID, a new tool for studying plant chromatin profiling in vivo, and its use to identify putative LHP1 target loci. Plant J. 48: 153-163.

GOMEZ-MENA, C., PINEIRO, M., FRANCO-ZORRILLA, J.M., SALINAS, J., COUPLAND, G., and MARTINEZ-ZAPATER, J.M. (2001). early bolting in short days: an Arabidopsis mutation that causes early flowering and partially suppresses the floral phenotype of leafy. Plant Cel/13: 1011-1024.

GOODRICH, J., and TWEEDIE, S. (2002). Remembrance of things past: chromatin remodeling in plant development. Annu. Rev. Cell Dev. Biol. 18: 707-746.

GOODRICH, J., PUANGSOMLEE, P., MARTIN, M., LONG, D., MEYEROWITZ, E.M., and COUPLAND, G. (1997). A Polycomb-group gene regulates homeotic gene expression in Arabidopsis. Nature 386: 44-51.

GREB, T., MYLNE, J.S., CREVILLEN, P., GERALDO, N., AN, H., GENDALL, A.R., and DEAN, C. (2007). The PHD finger protein VRN5 functions in the epigenetic silencing of Arabidopsis FLC. Curr. Biol. 17: 73-78.

GROSSNIKLAUS U, VIELLE-CALZADA JP, HOEPPNER MA, GAGLIANO WB. (1998). Maternal control of embryogenesis by MEDEA, a polycomb group gene in Arabidopsis. Science 280, 446-450.

GUO, L., ZHOU, J., ELLING, A.A., CHARRON, J.B. and DENG, X.W. (2008). Histone modifications and expression of light-regulated genes in Arabidopsis are cooperatively influenced by changing light conditions. Plant Physiol. 147: 2070-2083.

GUYOMARC'H, S., VERNOUX, T., TRAAS, J., ZHOU, D.X., and DELARUE, M. (2004). MGOUN3, an Arabidopsis gene with TetratricoPeptide-Repeat-related motifs, regulates meristem cellular organization. J. Exp. Bot. 55: 673-684.

GUYOMARC'H S., BERTRAND C., DELARUE M., and ZHOU D.X. (2005). Regulation of meristem activity by chromatin remodeling. Trends Plant Sci. 10: 332338.

HAECKER, A., GROSS-HARDT, R., GEIGES, B., SARKAR, A., BREUNINGER, H., HERRMANN, M., and LAUX, T. (2004). Expression dynamics of WOXgenes mark cell fate decisions during early embryonic patterning in Arabidopsis thaliana. Development 131: 657-668.

HE, Y., MICHAELS, S.D., and AMASINO, R.M. (2003). Regulation of flowering time by histone acetylation in Arabidopsis. Science 302: 1751-1754.

HE, Y., DOYLE, M.R., and AMASINO, R.M. (2004). PAF1-complex-mediated histone methylation of FLOWERING LOCUS C chromatin is required for the vernalization-responsive, winter-annual habit in Arabidopsis. Genes Dev. 18: 2774-2784.

HEDIGER F. and GASSER S.M. (2006). Heterochromatin protein 1: don't judge the book by its cover!"Curr. Opin. Genet. Dev.16:143-150.

HENDERSON, I.R. and JACOBSEN, S,E. (2007). Epigenetic inheritance in plants. Nature 447: 418-424.

HENDERSON, J.T., LI, H.C., RIDER, S.D., MORDHORST, A.P., ROMEROSEVERSON, J., CHENG, J.C., ROBEY, J., SUNG, Z.R., DE VRIES, S.C., and OGAS, J. (2004). PICKLE acts throughout the plant to repress expression of embryonic traits and may play a role in gibberellin-dependent responses. Plant Physiol. 134: 995-1005.

HENNIG, L., TARANTO, P., WALSER, M., SCHONROCK, N., and GRUISSEM, W. (2003). Arabidopsis MSI1 is required for epigenetic maintenance of reproductive development. Development 130: 2555-2565.

HIRAYAMA, J., SAHAR, S., GRIMALDI, B., TAMARU, T., TAKAMATSU, K., NAKAHATA, Y. and SASSONE-CORSI, P. (2007). CLOCK-mediated acetylation of BMAL1 controls circadian function. Nature 450: 1086-1090.

HSIEH, T.F., and FISCHER, R.L. (2005). Biology of chromatin dynamics. Annu. Rev. Plant Biol. 56: 327-351.

HURTADO, L., FARRONA, S., and REYES, J.C. (2006). The putative SWI/SNF complex subunit BRAHMA activates flower homeotic genes in Arabidopsis thaliana. Plant Mol. Biol. 62: 291-304.

IMAIZUMI, T., and KAY, S.A. (2006). Photoperiodic control of flowering: not only by coincidence. Trends Plant Sci. 11: 550-558.

JENUWEIN, T., and ALLIS, C.D. (2001). Translating the histone code. Science293: 1074-1080. 
JIANG, D., WANG, Y., WANG, Y. and HE, Y. (2008). Repression of FLOWERING LOCUS Cand FLOWERING LOCUS Thy the Arabidopsis Polycomb repressive complex 2 components. PLOS ONE. 3: e3404.

JIANG, D., YANG, W., HE, Y. and AMASINO, R.M. (2007). Arabidopsis relatives of the human lysine-specific Demethylase1 repress the expression of FWA and FLOWERING LOCUS C and thus promote the floral transition. Plant Cell. 19: 2975-2987.

JIAO Y., LAU O.S., and DENG X.W. (2007). Light-regulated transcriptional networks in higher plants. Nat. Rev. Genet. 8:217-230.

KATZ, A., OLIVA, M., MOSQUNA, A., HAKIM, O., and OHAD, N. (2004). FIE and CURLY LEAF polycomb proteins interact in the regulation of homeobox gene expression during sporophyte development. Plant J. 37: 707-719.

KAYA, H., SHIBAHARA, K.I., TAOKA, K.I., IWABUCHI, M., STILLMAN, B., and ARAKI, T. (2001). FASCIATA genes for chromatin assembly factor-1 in Arabidopsis maintain the cellular organization of apical meristems. Cel/104: 131-142.

KIM, J.M., TO, T.K., ISHIDA, J., MOROSAWA, T., KAWASHIMA, M., MATSUI, A., TOYODA, T., KIMURA, H., SHINOZAKI, K. and SEKI, M. (2008). Alterations of lysine modifications on the histone $\mathrm{H} 3 \mathrm{~N}$-tail under drought stress conditions in Arabidopsis thaliana. Plant Cell Physiol. 49: 1580-1588.

KIM, S., CHOI, K., PARK, C., HWANG, H.J., and LEE, I. (2006). SUPPRESSOROF FRIGIDA 4, encoding a C2H2-Type zinc finger protein, represses flowering by transcriptional activation of Arabidopsis FLOWERING LOCUS C. Plant Cel/18: 2985-2998.

KIM, S.Y., and MICHAELS, S.D. (2006). SUPPRESSOR OF FR/ 4 encodes a nuclear-localized protein that is required for delayed flowering in winter-annual Arabidopsis. Development 133: 4699-4707.

KIM, S.Y., HE, Y., JACOB, Y., NOH, Y.S., MICHAELS, S., and AMASINO, R. (2005). Establishment of the vernalization-responsive, winter-annual habit in Arabidopsis requires a putative histone $\mathrm{H} 3$ methyl transferase. Plant Cel/17: 3301-3310

KIM, H.J., HYUN, Y., PARK, J.Y., PARK, M.J., PARK, M.K., KIM, M.D., KIM, H.J., LEE, M.H., MOON, J., LEE, I., and KIM, J. (2004). A genetic link between cold responses and flowering time through FVE in Arabidopsis thaliana. Nat. Genet. 36: 167-171.

KINOSHITA, T., HARADA, J.J., GOLDBERG, R.B., and FISCHER, R.L. (2001). Polycomb repression of flowering during early plant development. Proc. Natt. Acad. Sci. USA 98: 14156-14161.

KIRIK, A., PECINKA, A., WENDELER, E., and REISS, B. (2006). The Chromatin Assembly Factor Subunit FASCIATA1 Is Involved in Homologous Recombination in Plants. Plant Ce//18: 2431-2442.

KÖHLER, C. and VILLAR, C,B. (2008). Programming of gene expression by Polycomb group proteins. Trends Cel/ Biol. 18: 236-243.

KOHLER, C., and MAKAREVICH, G. (2006). Epigenetic mechanisms governing seed development in plants. EMBO Rep. 7: 1223-1227.

KOHLER, C., HENNIG, L., SPILLANE, C., PIEN, S., GRUISSEM, W., and GROSSNIKLAUS, U. (2003). The Polycomb-group protein MEDEA regulates seed development by controlling expression of the MADS-box gene PHERES1. Genes Dev. 17: 1540-1553.

KOTAKE, T., TAKADA, S., NAKAHIGASHI, K., OHTO, M., and GOTO, K. (2003). Arabidopsis TERMINAL FLOWER 2 gene encodes a heterochromatin protein 1 homolog and represses both FLOWERING LOCUS Tto regulate flowering time and several floral homeotic genes. Plant Cell Physiol. 44: 555-564.

KOUZARIDES T. (2007). Chromatin modifications and their function. Cell. 128: 693-705.

KRICHEVSKY, A., GUTGARTS, H., KOZLOVSKY, S.V., TZFIRA, T., SUTTON, A., STERNGLANZ, R., MANDEL, G., and CITOVSKY, V. (2007). C2H2 zinc fingerSET histone methyltransferase is a plant-specific chromatin modifier. Dev. Biol. 303: 259-269.

KROGAN, N.J., KIM, M., TONG, A., GOLSHANI, A., CAGNEY, G., CANADIEN, V., RICHARDS, D.P., BEATTIE, B.K., EMILI, A., BOONE, C., SHILATIFARD, A., BURATOWSKI, S., and GREENBLATT, J. (2003). Methylation of histone H3 by Set2 in Saccharomyces cerevisiae is linked to transcriptional elongation by RNA polymerase II. Mol. Cell Biol. 23: 4207-4218.

KWON, C.S. and WAGNER, D. (2007). Unwinding chromatin for development and growth: a few genes at a time. Trends Genet. 23: 403-412.
KWON C.S., HIBARA K, PFLUGER J, BEZHANI S, METHA H, AIDA M, TASAKA $M$, and WAGNER D. (2006). A role for chromatin remodeling in regulation of CUC gene expression in the Arabidopsis cotyledon boundary. Development 133: 3223-3230.

KWON, C.S., CHEN, C., and WAGNER, D. (2005). WUSCHEL is a primary target for transcriptional regulation by SPLAYED in dynamic control of stem cell fate in Arabidopsis. Genes Dev. 19: 992-1003.

LÁZARO, A., GÓMEZ-ZAMBRANO, A. LÓPEZ-GONZALEZ, L., PIÑEIRO, M., and JARILLO, J.A. (2008). Mutations in the Arabidopsis SWC6, a component of the SWR1 chromatin remodelling complex, accelerate flowering time and alter leaf and flower development. J. Exp. Botany, 59: 653-666.

LEE, T.I., JENNER, R.G., BOYER, L.A., GUENTHER, M.G., LEVINE, S.S., KUMAR, R.M., CHEVALIER, B., JOHNSTONE, S.E., COLE, M.F., ISONO, K., KOSEKI, H., FUCHIKAMI, T., ABE, K., MURRAY, H.L., ZUCKER, J.P., YUAN, B., BELL, G.W., HERBOLSHEIMER, E., HANNETT, N.M., SUN, K., ODOM, D.T., OTTE, A.P., VOLKERT, T.L., BARTEL, D.P., MELTON, D.A., GIFFORD, D.K., JAENISCH, R., and YOUNG, R.A. (2006a). Control of developmental regulators by Polycomb in human embryonic stem cells. Cel/125: 301-313.

LEE MG, WYNDER C, BOCHAR DA, HAKIMI MA, COOCH N, and SHIEKHATTAR R. (2006b) Functional interplay between histone demethylase and deacetylase enzymes. Mol. Cell Biol. 26: 6395-6402.

LEE, K. K., and WORKMAN, J. L (2007). Histone acetyltransferase complexes: one size doesn't fit all. Nat. Rev. Mol. Cell Biol. 8: 284-295

LEYSER, H.M., and FURNER, I.J. (1992). Characterisation of three shoot apical meristem mutants of Arabidopsis thaliana. Development 116: 397-403.

LI, H.C., CHUANG, K., HENDERSON, J.T., RIDER, S.D., JR., BAI, Y., ZHANG, H., FOUNTAIN, M., GERBER, J., and OGAS, J. (2005). PICKLE acts during germination to repress expression of embryonic traits. Plant J. 44: 1010-1022.

LIBAULT, M., TESSADORI, F., GERMANN, S., SNIJDER, B., FRANSZ, P., and GAUDIN, V. (2005). The Arabidopsis LHP1 protein is a component of euchromatin. Planta 222: 910-925

LIU Y., KOORNNEEF M., and SOPPE W.J. (2007). The absence of histone H2B monoubiquitination in the Arabidopsis hub1 (rdo4) mutant reveals a role for chromatin remodeling in seed dormancy. Plant Cel/19: 433-444

LOYOLA, A., and ALMOUZNI, G. (2004). Histone chaperones, a supporting role in the limelight. Biochim. Biophys. Acta 1677: 3-11.

MAKAREVICH, G., LEROY, O., AKINCI, U., SCHUBERT, D., CLARENZ, O. GOODRICH, J., GROSSNIKLAUS, U., and KOHLER, C. (2006). Different Polycomb group complexes regulate common target genes in Arabidopsis. EMBO Rep. 7: 947-952.

MAO, Y., PAVANGADKAR, K.A., THOMASHOW, M.F., and TRIEZENBERG, S.J. (2006). Physical and functional interactions of Arabidopsis ADA2 transcriptional coactivator proteins with the acetyltransferase GCN5 and with the cold-induced transcription factor CBF1. Biochim. Biophys. Acta 1759: 69-79.

MARCH-DIAZ, R., GARCIA-DOMINGUEZ, M., FLORENCIO, F.J., and REYES, J.C. (2007). SEF, a new protein required for flowering repression in Arabidopsis, interacts with PIE1 and ARP6. Plant Physiol. 143: 893-901.

MARTIN-TRILLO, M., LAZARO, A., POETHIG, R.S., GOMEZ-MENA, C., PINEIRO, M.A., MARTINEZ-ZAPATER, J.M., and JARILLO, J.A. (2006). EARLY IN SHORT DAYS 1 (ESD1) encodes ACTIN-RELATED PROTEIN 6 (AtARP6), a putative component of chromatin remodeling complexes that positively regulates FLC accumulation in Arabidopsis. Development 133: 1241-1252.

MELLOR, J. (2006). It takes a PHD to read the histone code. Cel/126: 22-24.

MULLER, J., HART, C.M., FRANCIS, N.J., VARGAS, M.L., SENGUPTA, A., WILD, B., MILLER, E.L., O' CONNOR M.B., KINGSTON, R.E., and SIMON, J.A. (2002). Histone methyl-transferase activity of a Drosophila Polycomb group repressor complex. Cel/111: 197-208.

MLYNAROVA L., NAP J.P., and BISSELING T. (2007). The SWI/SNF chromatinremodeling gene AtCHR12 mediates temporary growth arrest in Arabidopsis thaliana upon perceiving environmental stress. Plant J. 51: 874-885.

MYLNE, J.S., BARRETT, L., TESSADORI, F., MESNAGE, S., JOHNSON, L., BERNATAVICHUTE, Y.V., JACOBSEN, S.E., FRANSZ, P., and DEAN, C. (2006). LHP1, the Arabidopsis homologue of HETEROCHROMATIN PROTEIN1, is required for epigenetic silencing of FLC. Proc. Natl. Acad. Sci. USA 103: 5012-5017.

NAKAHIGASHI, K., JASENCAKOVA, Z., SCHUBERT, I., and GOTO, K. (2005) 
The Arabidopsis heterochromatin protein1 homolog (TERMINAL FLOWER2) silences genes within the euchromatic region but not genes positioned in heterochromatin. Plant Cell Physiol. 46: 1747-1756.

NG, H.H., DOLE, S., and STRUHL, K. (2003). The Rtf1 component of the Paf1 transcriptional elongation complex is required for ubiquitination of histone $\mathrm{H} 2 \mathrm{~B}$. J. Biol. Chem. 278: 33625-33628.

NOH, B., LEE, S.H., KIM, H.J., YI, G., SHIN, E.A., LEE, M., JUNG, K.J., DOYLE, M.R., AMASINO, R.M., and NOH, Y.S. (2004). Divergent roles of a pair of homologous jumonji/zinc-finger-class transcription factor proteins in the regulation of Arabidopsis flowering time. Plant Cel/16: 2601-2613.

OGAS, J., KAUFMANN, S., HENDERSON, J., and SOMERVILLE, C. (1999). PICKLE is a CHD3 chromatin-remodeling factor that regulates the transition from embryonic to vegetative development in Arabidopsis. Proc. Natl. Acad. Sci. USA 96: 13839-13844.

$\mathrm{OH}$, S., PARK, S. and VAN NOCKER, S. (2008). Genic and global functions for Paf1C in chromatin modification and gene expression in Arabidopsis. PLOS Genet. 4: e1000077.

OH, S., ZHANG, H., LUDWIG, P., and VAN NOCKER, S. (2004). A mechanism related to the yeast transcriptional regulator $P$ af $1 \mathrm{c}$ is required for expression of the Arabidopsis FLC/MAFMADS box gene family. Plant Cel/16: 2940-2953.

OHAD N, YADEGARI R, MARGOSSIAN L, HANNON M, MICHAELI D, HARADA JJ, GOLDBERG RB, FISCHER RL. (1999). Mutations in FIE, a WD polycomb group gene, allow endosperm development without fertilization. Plant Cell. 11, 407-416.

ONO, T., KAYA, H., TAKEDA, S., ABE, M., OGAWA, Y., KATO, M., KAKUTANI, T., MITTELSTEN SCHEID, O., ARAKI, T., and SHIBAHARA, K. (2006). Chromatin assembly factor 1 ensures the stable maintenance of silent chromatin states in Arabidopsis. Genes Cells 11: 153-162.

ORI, N., ESHED, Y., CHUCK, G., BOWMAN, J.L., and HAKE, S. (2000). Mechanisms that control knox gene expression in the Arabidopsis shoot. Development 127: 5523-5532.

PEPPER A, DELANEY T, WASHBURN T, POOLE D, CHORY J. (1994). DET1, a negative regulator of light-mediated development and gene expression in Arabidopsis, encodes a novel nuclear-localized protein. Ce//78, 109-116.

PERALES, M., and MAS, P. (2007). A Functional Link between Rhythmic Changes in Chromatin Structure and the Arabidopsis Biological Clock. Plant Cell 19: 2111-2123.

PEI, Y, NIU, L., LU, F., LIU, C., ZHAI, J., KOMG, X., and Cao, X. (2007). Mutations in the Type II protein arginine methyltransferase AtPRMT5 result in pleiotropic developmental defects in Arabidopsis. Plant Physiol. 144: 1913-1923.

PFLUGER, J. and WAGNER, D. (2007). Histone modifications and dynamic regulation of genome accessibility in plants. Curr. Opin. Plant Biol. 10: 645-652.

PIEN, S., FLEURY, D., MYLNE, J.S., CREVILLEN, P., INZÉ, D., AVRAMOVA, Z., DEAN, C. and GROSSNIKLAUS, U. (2008). ARABIDOPSIS TRITHORAX1 dynamically regulates FLOWERING LOCUS Cactivation via histone 3 lysine 4 trimethylation. Plant Cell. 20: 580-588.

PIEN, S., and GROSSNIKLAUS, U. (2007). Polycomb group and trithorax group proteins in Arabidopsis. Biochimica et Biophysica Acta 1769: 375-82.

PINEIRO, M., GOMEZ-MENA, C., SCHAFFER, R., MARTINEZ-ZAPATER, J.M., and COUPLAND, G. (2003). EARL Y BOL TING IN SHORT DAYS is related to chromatin remodeling factors and regulates flowering in Arabidopsis by repressing FT. Plant Cel/15: 1552-1562.

RAMIREZ-PARRA, E. and GUTIERREZ, C. (2007).The many faces of chromatin assembly factor 1 . Trends Plant Sci. 12: 570-576.

RANDO, O.J. (2007). Global patterns of histone modifications. Curr. Opin. Genet. Dev. 17: 94-99.

REYES, J.C. (2006). Chromatin modifiers that control plant development. Curr. Opin. Plant Biol. 9: 21-27.

RIDER, S.D., JR., HEMM, M.R., HOSTETLER, H.A., LI, H.C., CHAPPLE, C., and OGAS, J. (2004). Metabolic profiling of the Arabidopsis pk/mutant reveals selective derepression of embryonic traits. Planta 219: 489-499.

RINGROSE, L., and PARO, R. (2004). Epigenetic regulation of cellular memory by the Polycomb and Trithorax group proteins. Annu. Rev. Genet. 38: 413-443.

RINGROSE, L., and PARO, R. (2007). Polycomb/Trithorax response elements and epigenetic memory of cell identity. Development 134: 223-232.
RIPPERGER, J.A., and SCHIBLER, U. (2006). Rhythmic CLOCK-BMAL1 binding to multiple E-box motifs drives circadian Dbp transcription and chromatin transitions. Nat. Genet. 38: 369-374.

SABLOWSKI, R. (2004). Plant and animal stem cells: conceptually similar, molecularly distinct? Trends Cell Biology 14: 605-611.

SALEH, A., AL-ABDALLAT, A., NDAMUKONG, I., ALVAREZ-VENEGAS, R. and AVRAMOVA, Z. (2007). The Arabidopsis homologs of trithorax (ATX1) and enhancer of zeste (CLF) establish 'bivalent chromatin marks' at the silent AGAMOUS locus. Nucleic Acids Res. 35: 6290-6296.

SARKAR, A.K., LUIJTEN, M., MIYASHIMA, S., LENHARD, M., HASHIMOTO, T., NAKAJIMA, K., SCHERES, B., HEIDSTRA, R., and LAUX, T. (2007). Conserved factors regulate signalling in Arabidopsis thaliana shoot and root stem cell organizers. Nature 446: 811-814.

SARNOWSKI, T.J., RIOS, G., JASIK, J., SWIEZEWSKI, S., KACZANOWSKI, S., LI, Y., KWIATKOWSKA, A., PAWLIKOWSKA, K., KOZBIAL, M., KOZBIAL, P., KONCZ, C., and JERZMANOWSKI, A. (2005). SWI3 Subunits of Putative SWI/ SNF Chromatin-Remodeling Complexes Play Distinct Roles during Arabidopsis Development. Plant Cel/17: 2454-2472.

SCHERES, B. (2007). Stem-cell niches: nursery rhymes across kingdoms. Nat Rev. Mol. Cell Biol. 8: 345-354.

SCHMITZ, R.J, SUNG, S. and AMASINO, R.M. (2008). Histone arginine methylation is required for vernalization-induced epigenetic silencing of $F L C$ in winterannual Arabidopsis thaliana. Proc Natl Acad Sci USA 105: 411-416.

SCHMITZ, R.J., and AMASINO, R.M. (2007). Vernalization: a model for investigating epigenetics and eukaryotic gene regulation in plants. Biochim. Biophys. Acta 1769: 269-275.

SCHMITZ, R.J., HONG, L., FITZPATRICK, K.E., and AMASINO, R.M. (2007). DICER-LIKE 1 and DICER-LIKE 3 Redundantly Act to Promote Flowering via Repression of FLOWERING LOCUS C in Arabidopsis thaliana. Genetics 176 : 1359-1362.

SCHONROCK, N., BOUVERET, R., LEROY, O., BORGHI, L., KOHLER, C., GRUISSEM, W., and HENNIG, L. (2006). Polycomb-group proteins repress the floral activator $A G L 19$ in the $F L C$-independent vernalization pathway. Genes Dev. 20: 1667-1678.

SCHROEDER, D.F., GAHRTZ, M., MAXWELL, B.B., COOK, R.K., KAN, J.M., ALONSO, J.M., ECKER, J.R., and CHORY, J. (2002). De-etiolated 1 and damaged DNA binding protein 1 interact to regulate Arabidopsis photomorphogenesis. Curr. Biol. 12: 1462-1472.

SCHUBERT, D., PRIMAVESI, L., BISHOPP, A., ROBERTS, G., DOONAN, J., JENUWEIN, T., and GOODRICH, J. (2006). Silencing by plant Polycomb-group genes requires dispersed trimethylation of histone $\mathrm{H} 3$ at lysine 27. EMBO J.25, 4638-4649.

SCHWARTZ, Y.B. and PIRROTTA, V. (2008). Polycomb complexes and epigenetic states. Curr. Opin. Cell Biol. 20: 266-273.

SEXTON T, SCHOBER H, FRASER P, and GASSER SM. (2007). Gene regulation through nuclear organization. Nat Struct Mol Biol. 14, 1049-1055.

SHELDON, C.C., HILLS, M.J., LISTER, C., DEAN, C., DENNIS, E.S. and PEACOCK, W.J. (2008). Resetting of FLOWERING LOCUS C expression after epigenetic repression by vernalization. Proc Natl Acad Sci USA. 105: 2214 2219.

SHELDON, C.C., FINNEGAN, E.J., DENNIS, E.S., and PEACOCK, W.J. (2006). Quantitative effects of vernalization on FLC and SOC1 expression. Plant J. 45: 871-883.

SHI Y., LAN F., MATSON C., MULLIGAN P., WHETSTINE J.R., COLE P.A., CASERO R.A., and SHI Y. (2004). Histone demethylation mediated by the nuclear amine oxidase homolog LSD1. Cel/119: 941-53.

SINGH, J., FREELING, M. and LISCH, D. (2008) A position effect on the heritability of epigenetic silencing. PLOS Genet. 4: e1000216.

SMITH, C.L., and PETERSON, C.L. (2005). ATP-dependent chromatin remodeling. Curr. Top. Dev. Biol. 65: 115-148.

STOCKINGER, E.J., MAO, Y., REGIER, M.K., TRIEZENBERG, S.J., and THOMASHOW, M.F. (2001). Transcriptional adaptor and histone acetyltransferase proteins in Arabidopsis and their interactions with CBF1, a transcriptional activator involved in cold-regulated gene expression. Nucleic Acids Res. 29: 1524-1533.

STRAHL, B.D., and ALLIS, C.D. (2000). The language of covalent histone modifi- 
cations. Nature 403: 41-45.

SU Y., KWON C.S., BEZHANI S., HUVERMANN B., CHEN C., PERAGINE A., KENNEDY J.F., and WAGNER D. (2006). The N-terminal ATPase AT-hookcontaining region of the Arabidopsis chromatin-remodeling protein SPLAYED is sufficient for biological activity. Plant J. 46: 685-99.

SUNG, S., and AMASINO, R.M. (2004). Vernalization in Arabidopsis thaliana is mediated by the PHD finger protein VIN3. Nature 427: 159-164.

SUNG, S., and AMASINO, R.M. (2006). Molecular genetic studies of the memory of winter. J. Exp. Bot. 57: 3369-3377.

SUNG, S., SCHMITZ, R.J., and AMASINO, R.M. (2006a). A PHD finger protein involved in both the vernalization and photoperiod pathways in Arabidopsis. Genes Dev. 20: 3244-3248.

SUNG, S., HE, Y., ESHOO, T.W., TAMADA, Y., JOHNSON, L., NAKAHIGASHI, K., GOTO, K., JACOBSEN, S.E., and AMASINO, R.M. (2006b). Epigenetic maintenance of the vernalized state in Arabidopsis thalianarequires LIKE HETEROCHROMATIN PROTEIN 1. Nat. Genet. 38: 706-710.

SUZUKI, T., NAKAJIMA, S., INAGAKI, S., HIRANO-NAKAKITA, M., MATSUOKA, K., DEMURA, T., FUKUDA, H., MORIKAMI, A., and NAKAMURA, K. (2005). TONSOKU is Expressed in S Phase of the Cell Cycle and its Defect Delays Cell Cycle Progression in Arabidopsis. Plant Cell Physiol. 46: 736-742.

SUZUKI, T., INAGAKI, S., NAKAJIMA, S., AKASHI, T., OHTO, M.-A., KOBAYASHI, M., SEKI, M., SHINOZAKI, K., KATO, T., TABATA, S., NAKAMURA, K., and MORIKAMI, A. (2004). A novel Arabidopsis gene TONSOKU is required for proper cell arrangement in root and shoot apical meristems. Plant J. 38: 673684.

SWIEZEWSKI, S., CREVILLEN, P., LIU, F., ECKER, J.R., JERZMANOWSKI, A., and DEAN, C. (2007). Small RNA-mediated chromatin silencing directed to the 3 ' region of the Arabidopsis gene encoding the developmental regulator, $F L C$. Proc. Natl. Acad. Sci. USA 104: 3633-3638.

TAKADA, S., and GOTO, K. (2003). TERMINAL FLOWER2, an Arabidopsis homolog of HETEROCHROMATIN PROTEIN1, counteracts the activation of FLOWERING LOCUS T by CONSTANS in the vascular tissues of leaves to regulate flowering time. Plant Cel/15: 2856-2865.

TAKEDA, S., TADELE, Z., HOFMANN, I., PROBST, A.V., ANGELIS, K.J., KAYA, H., ARAKI, T., MENGISTE, T., MITTELSTEN SCHEID, O., SHIBAHARA, K., SCHEEL, D., and PASZKOWSKI, J. (2004). BRU1, a novel link between responses to DNA damage and epigenetic gene silencing in Arabidopsis. Genes Dev. 18: 782-793.

TESSADORI, F., CHUPEAU, M.C., CHUPEAU, Y., KNIP, M., GERMANN, S., VAN DRIEL, R., FRANSZ, P., and GAUDIN, V. (2007). Large-scale dissociation and sequential reassembly of pericentric heterochromatin in dedifferentiated Arabidopsis cells. J. Cell Sci. 120: 1200-1208.

TURCK, F., ROUDIER, F., FARRONA, S., MARTIN-MAGNIETTE, M.L., GUILLAUME, E., BUISINE, N., GAGNOT, S., MARTIENSSEN, R.A., COUPLAND, G., and COLOT, V. (2007). Arabidopsis TFL2/LHP1 specifically associates with genes marked by trimethylation of histone $\mathrm{H} 3$ Lysine 27. PLOS Genet. 3: e86.

VAILLANT, I. and PASZKOWSKI, J. (2007). Role of histone and DNA methylation in gene regulation. Curr. Opin. Plant Biol. 10: 528-533.

VAN VUGT, J.J., RANES, M., CAMPSTEIJN, C., and LOGIE, C. (2007). The ins and outs of ATP-dependent chromatin remodeling in budding yeast: biophysical and proteomic perspectives. Biochim. Biophys. Acta 1769: 153-171.

VERDEIL, J.L., ALEMANNO, L., NIEMENAK, N. and TRANBARGER, T.J. (2007).
Pluripotent versus totipotent plant stem cells: dependence versus autonomy? Trends Plant Sci. 12: 245-252.

VLACHONASIOS, K.E., THOMASHOW, M.F., and TRIEZENBERG, S.J. (2003). Disruption mutations of $A D A 2 b$ and $G C N 5$ transcriptional adaptor genes dramatically affect Arabidopsis growth, development, and gene expression. Plant Cel/15: 626-638.

WAGNER, D., and MEYEROWITZ, E.M. (2002). SPLAYED, a novel SWI/SNF ATPase homolog, controls reproductive development in Arabidopsis. Curr. Biol. 12: 85-94.

WANG, X., ZHANG, Y., MA, Q., ZHANG, Z., XUE, Y., BAO, S., and CHONG, K (2007). SKB1-mediated symmetric dimethylation of histone H4R3 controls flowering time in Arabidopsis. EMBO J. 26: 1934-1941

WOOD, C.C., ROBERTSON, M., TANNER, G., PEACOCK, W.J., DENNIS, E.S and HELLIWELL, C.A. (2006). The Arabidopsis thalianavernalization response requires a polycomb-like protein complex that also includes VERNALIZATION INSENSITIVE 3. Proc. Natl. Acad. Sci. USA 103: 14631-14636.

XU, L., ZHAO, Z., DONG, A., SOUBIGOU-TACONNAT, L., RENOU, J.P., STEINMETZ, A. and SHEN, W.H. (2008). Di- and tri- but not monomethylation on histone $\mathrm{H} 3$ lysine 36 marks active transcription of genes involved in flowering time regulation and other processes in Arabidopsis thaliana. Mol. Cel/ Biol. 28 1348-1360.

YANAGAWA Y., SULLIVAN J.A., KOMATSU S., GUSMAROLI G., SUZUKI G., YIN J., ISHIBASHI T., SAIJO Y., RUBIO V., KIMURA S., WANG J., and DENG X.W. (2004).Arabidopsis COP10 forms a complex with DDB1 and DET1 in vivo and enhances the activity of ubiquitin conjugating enzymes. Genes Dev. 18: 21722181.

YOSHIDA N, YANAI Y, CHEN L, KATO Y, HIRATSUKA J, MIWA T, SUNG ZR, TAKAHASHI S. (2001). EMBRYONIC FLOWER2, a novel polycomb group protein homolog, mediates shoot development and flowering in Arabidopsis. Plant Cel/13, 2471-2481.

ZHANG, X., CLARENZ, O., COKUS, S., BERNATAVICHUTE, Y.V., PELLEGRINI, M., GOODRICH, J., and JACOBSEN, S.E. (2007a). Whole-genome analysis of histone $\mathrm{H} 3$ lysine 27 trimethylation in Arabidopsis. PLOS Biol. 5: e129

ZHANG X., GERMANN S., BLUS B.J., KHORASANIZADEH S., GAUDIN V., and JACOBSEN S.E.(2007b). The Arabidopsis LHP1 protein colocalizes with histone H3 Lys27 trimethylation. Nat. Struct. Mol. Biol. 14: 869-871.

ZHANG, X., YAZAKI, J., SUNDARESAN, A., COKUS, S., CHAN, S.W., CHEN, H., HENDERSON, I.R., SHINN, P., PELLEGRINI, M., JACOBSEN, S.E., and ECKER, J.R. (2006). Genome-wide high-resolution mapping and functional analysis of DNA methylation in arabidopsis. Cel/126: 1189-1201.

ZHANG, $\mathrm{H}$. and VAN NOCKER, S. (2002). The VERNALIZATION INDEPENDENCE 4 gene encodes a novel regulator of FLOWERING LOCUS C. Plant J. 31: 663-673.

ZHAO, Z., YU, Y., MEYER, D., WU, C., and SHEN, W.H. (2005). Prevention of early flowering by expression of FLOWERING LOCUS C requires methylation of histone H3 K36. Nat. Cell. Biol. 7: 1256-1260.

ZHU, J., JEONG, J.C., ZHU, Y., SOKOLCHIK, I., MIYAZAKI, S., ZHU, J.K., HASEGAWA, P.M., BOHNERT, H.J., SHI, H., YUN, D.J. and BRESSAN R.A.(2008). Involvement of Arabidopsis HOS15 in histone deacetylation and cold tolerance. Proc Natl Acad Sci USA. 105: 4945-4950.

ZHU Y., DONG A., MEYER D., PICHON O., RENOU J.P., CAO K., SHEN W.H. (2006). Arabidopsis NRP1 and NRP2 encode histone chaperones and are required for maintaining postembryonic root growth. Plant Cel/18: 2879-2892. 


\section{Further Related Reading, published previously in the Int. J. Dev. Biol.}

See our recent Special Issue Fertilization, in honor of David L. Garbers and edited by Paul M. Wassarman and Victor D. Vacquier at: http://www.ijdb.ehu.es/web/contents.php?vol=52\&issue=5-6

See our recent Special Issue Plant Development, edited by José Luis Micol and Miguel A. Blázquez at:

http://www.ijdb.ehu.es/web/contents.php?vol=49\&issue=5-6

Regulated RNA processing in the control of Arabidopsis flowering Victor Quesada, Caroline Dean and Gordon G. Simpson Int. J. Dev. Biol. (2005) 49: 773-780

\section{Environmental regulation of flowering}

Israel Ausín, Carlos Alonso-Blanco and José-Miguel Martínez-Zapater Int. J. Dev. Biol. (2005) 49: 689-705

Flowering: a time for integration

François Parcy

Int. J. Dev. Biol. (2005) 49: 585-593

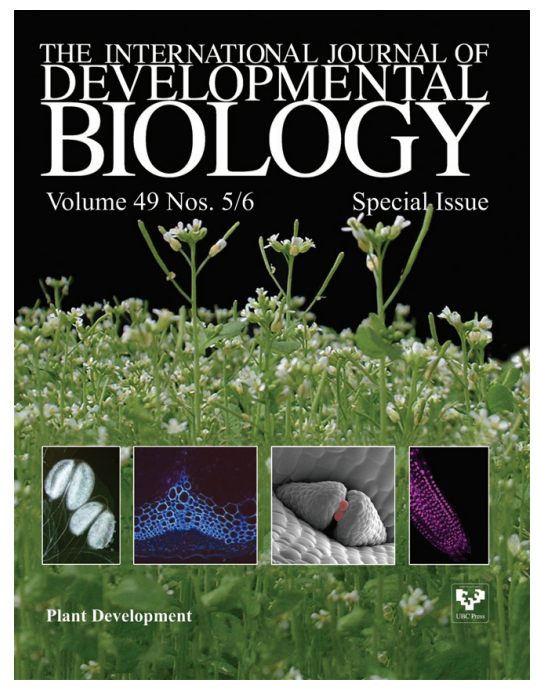

5 yr ISI Impact Factor $(2008)=3.271$

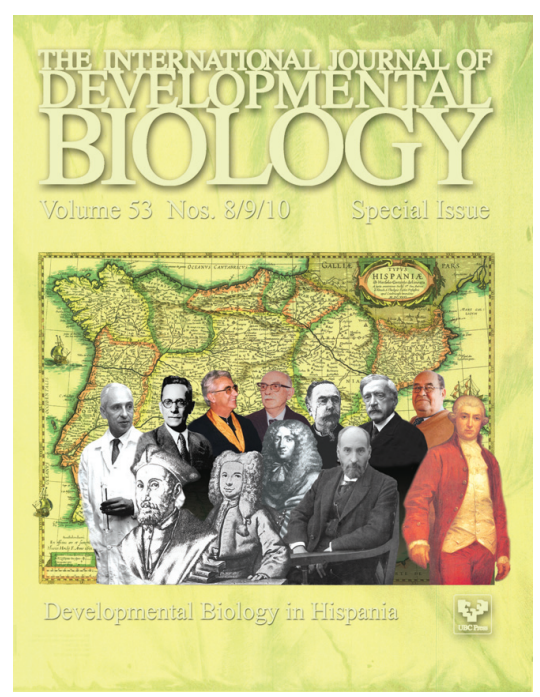

